Portland State University

PDXScholar

\title{
Building Wooden Houses: The Political Economy of Plankhouse Construction on the Southern Northwest Coast of North America
}

\author{
Kenneth M. Ames \\ Portland State University, amesk@pdx.edu \\ Emily E. Shepard \\ Portland State University
}

Follow this and additional works at: https://pdxscholar.library.pdx.edu/anth_fac

Part of the Anthropology Commons

Let us know how access to this document benefits you.

\begin{abstract}
Citation Details
Published as: Ames, K. M., \& Shepard, E. E. (2019). Building wooden houses: The political economy of plankhouse construction on the southern Northwest Coast of North America. Journal of Anthropological Archaeology, 53, 202-221.
\end{abstract}

This Post-Print is brought to you for free and open access. It has been accepted for inclusion in Anthropology Faculty Publications and Presentations by an authorized administrator of PDXScholar. Please contact us if we can make this document more accessible: pdxscholar@pdx.edu. 
Building Wooden Houses: The Political Economy of Plankhouse Construction on the southern Northwest Coast of North America.

\author{
Kenneth M. Ames ${ }^{\text {a }}$ \\ amesk@pdx.edu \\ Emily E. Shepard ${ }^{\mathrm{a}}$ \\ emilyevelynshepard@gmail.com
}

a Department of Anthropology, Portland State University, Portland Or. USA 97207

*Corresponding author 


\begin{abstract}
Household archaeology focuses on what households do. Building and repairing houses is a household task that receives less explicit attention than do other tasks. Through the lens of political economy, we examine how three southern Northwest Coast households organized and orchestrated a complex labor task: building and maintaining their houses, by developing estimates of labor and raw material costs. We then use this analysis to show how house building and maintenance bears on issues of collective action, monumentality, anthropogenic landscapes, the development of concepts of property on the Northwest Coast, and of household continuity across episodes of cultural change. The political economies of Northwest Coast households have been central to theory building about the evolution and nature of sociocultural complexity among complex hunter-gatherer-fisher societies, but archaeological attention has emphasized subsistence. Our analysis does not supplant such models, but rather compliments them.
\end{abstract}

Keywords: Household archaeology, labor estimates, monumentality, property, anthropogenic landscapes, collective action, Northwest Coast 
[C]ollective production beyond the unit of the simple family was necessary. The building and maintenance of the house, which had to be made from heavy cedar planks with stone tools, required a long period of effort (Oberg, 1943, p. 579, referring to the Tlingit).

Building a house in former times was a feat involving control of a considerable amount of manpower, which in turn depended on economic resources to support the people while they worked, with enough surplus to give feasts and other diversions to entertain them...it was not undertaken casually, nor...very often. The old houses are said to last almost indefinitely...over a long period, the entire roof and siding of a house might be renewed, and one by one the posts and beams...replaced, but it would still be the same old house that had stood in that place since...the dim epochs of traditional times (Drucker, 1951, p. 72-73, referring to the Nootka (Nuu-chah-nulth)

\section{Introduction}

We examine how three Northwest Coast households organized and orchestrated a complex labor task: building and maintaining their houses. We use this analysis to show how house building and maintenance bears on issues of collective action, political economy, monumentality, anthropogenic landscapes, the development of concepts of property on the coast, and of household continuity. This paper is in the spirit of Fladmark's (1973) imperative that Northwest Coast archaeology actively test Northwest Coast ethnography and is an exercise in what Ames (2008: 139-140) calls "ropewalk work", following Wylie's nautical metaphor of archaeologists weaving cables of evidence (Wylie, 1989). Before being woven together, the strands forming a cable were laid side by side in ropewalks and tested against each other for strength. Here the cables of evidence are archaeological and ethnographic, as epitomized by the quotes opening this paper.

Household archaeology emphasizes what households do: household production, distribution, transmission or inheritance, reproduction, and coresidence (Douglass and Gonlin, 2012; Wilk and Netting, 1984). Households also build and repair houses, activities materializing the household across time and which intersect with architecture and household function. House building opens a window into the household's political economy by requiring raw materials, labor, skills, organization, and social networks; requirements that can have unexpected ramifying effects. When considering houses, archaeologists usually focus on the social and ideological information derivable from a structure's layout and architecture (e.g. Blanton, 1994; Coudart, 2015; Coupland et al., 2009; Grier, 2006a; Steadman, 2015; Steere, 2017). Surprisingly, household archaeology has shown little interest in house building. For example, Steadman's (2015) encyclopedic treatment of the archaeology of domestic architecture has no sustained treatment of house construction and its implications. Souvatzi's (2008) stimulating study of Neolithic Greek households focuses on households as social process, but not on material processes such as construction. This apparent lack of interest results in part from methodological difficulties. Blanton (1994), for example, in his cross-cultural study of households and houses, tried to look at construction materials but found it difficult to draw comparisons. Labor estimates 
can be developed (e.g. Abrams, 1994) and compared, but this has first to be done on a case by case basis, as we do here. It is also results, at least in part, from taking the house qua built object for granted. We hope to change that. To do that, we draw upon household archaeology, political economy and collective action theory. This paper culminates a series of papers on the labor costs of Northwest Coast houses (Ames et al., 1992; Ames, 1996; Gahr, 2006; Shepard, 2017). We were originally concerned simply with labor costs by estimating the board feet of lumber necessary to cover a house as a solid geometric shape (Ames et al., 1992). This subsequently expanded to using these lumber estimates as measures of labor costs relative to house size and household status (Ames, 1996); to modelling the houses' life cycle, and estimating the numbers of people needed to erect houses if they were put up in a single day as was the practice in some parts of the coast (Gahr, 2006). The present discussion expands on the previous work by using mapped structural features (e.g. post and plank molds, wall trenches, etc.) (Shepard, 2017) to reconstruct the houses and their construction histories to estimate the numbers and weights of $\operatorname{logs}$, the person days required to build and maintain the structures, and analyze the houses' architectural stability through time as a measure of household continuity. We show that house construction was a significant undertaking, requiring substantial numbers of workers and materials. We also use these data to show that these particular houses were architecturally stable over their nearly half-millennia uselives.

\section{Northwest Coast Houses and Households}

Northwest Coast houses were the material expressions of extended, multifamily households. The houses themselves, the focus of this article, were commonly rectilinear post and beam structures (Fig. 1) built most often of Western redcedar (Thuja plicata) with redcedar forming the frame, planks, cladding, roofs, and floors (where floors were planked). Houses varied along the coast, most obviously in their roofs, some places had shed roofs, others gable roofs, but also in architectural details (Suttles, 1990; Vastokis, 1966). Jordan and O'Neill (2010) show this variation closely tracks language differences, although Mackie and Williamson (2003) describe a single village on the west coast of Vancouver Island that had most major variants in a single, seven house village. Hajda (1994) documents variations in house form and size in the Lower Columbia Region, where our research took place. Suttles (1991) enumerates their functions: dwelling, food processing and storage plant, workshop and recreation center, temple, theater, and fortress. While his list is specific to the shed roof houses of southeastern British Columbia and northwestern Washington State, it applies to the whole coast. The houses were where the nittygritty of household production and daily life intersected with social power and spirituality. Finally, they materialized and shaped the social and political dynamics of both their resident households and the village communities of which they were a part (e.g. Suttles 1991) while anchoring them in time and space (e.g. Marshall, 2006).

The households were the fundamental social, cultural, economic, political and legal building blocks of Northwest Coast societies. Membership could range from as few as 15 to well over 100 people. Recruitment varied from matrilineages in the north to greater genealogical flexibility and fluidity farther south, the ambiguity of which led Levi-Strauss (1983) to formulate his concept of House societies (société à maisons) among which the perpetuation of the House and its estate was the central organizing principle (see below). 
Small rectilinear houses are present in the archaeological record of the northern Northwest Coast by 6500 cal BP (Letham, et al., 2015; Martindale et al., 2017a). Larger houses appear there between 4500 and $3500 \mathrm{cal} \mathrm{BP}$ and are present thereafter. Substantial houses appear on the Salish Sea portion of the southern coast by ca 5800 cal BP (Lepofsky et al., 2009; Mason, 2017). There may be a gap in the record there between ca. 5000 and 3500 BP, but that might be attributable to sampling. Large rectilinear surface houses are sporadically present in the record thereafter $3500 \mathrm{BP}$ and are ubiquitous after ca. $2300 \mathrm{cal} \mathrm{BP.} \mathrm{On} \mathrm{the} \mathrm{Lower} \mathrm{Columbia,} \mathrm{houses} \mathrm{are}$ present in the record after ca 3000 cal BP, especially so after about 2000 cal BP (Ames and Sobel, 2013, Table 6.2). This local chronology is primarily a function of post-glacial sea level rise and the stabilization of the Columbia River flood plain by $2000 \mathrm{cal}$ BP. In sum, rectilinear houses are present here and there on the coast by ca $6000 \mathrm{cal} \mathrm{BP}$, if not earlier, and are widespread after 3000 cal BP.

\section{INSERT FIGURE 1 ABOUT HERE}

Archaeologists have seen these houses and their associated villages as evidence for many things: the development of the Northwest Coast ethnographic pattern (e.g. Matson and Coupland, 1995); of sedentism (e.g. Ames, 1981; Fladmark, 1975); of particular forms of labor organization (e.g. Ames and Maschner, 1999); as sources of social information, such as presence/absence of ranking (e.g. Archer, 2001; Coupland, 1985); of political information (e.g. Marshall, 1989); place-making (e.g. Marshall, 2006); production specialization (e.g. Chatters, 1989; Grier, 2001, Huelsbeck, 1988); as long-term persistence of social identities (e.g. Lepofsky et al., 2009) and of house groups or lineages (Martindale et al., 2017a); of the tension between communalism and hierarchy (Coupland et al., 2009); and of monumentality (Grier, 2006a). Archaeologists less often look at house construction. This mirrors a bias in the ethnographies, where the interest was much more on the social organization within the houses then on the houses themselves. It should be acknowledged though that by the time the ethnographic work was being done, many people were no longer living in plankhouses, and even fewer had probably seen one built. It is also in part a consequence of sampling and taphonomy, which is beyond the scope of this paper. But, in a sense, the existence of houses has been taken for granted and the demands of their construction and maintenance overlooked. For example, in a recent summary of environmental management practices on the coast and the uses of various resources, including wood, the authors list multiple uses for cedar - but not houses (Mathews and Turner, 2017, Table 9.2).

\section{The Sites: Meier and Cathlapotle}

The three plankhouses examined in this study are located in the Wapato Valley of the Greater Lower Columbia River Region (GLCRR) of western North America (Fig. 2) (Boyd et al., 2013; Hajda, 1984). Anthropologically, it is considered part of the southern sub-region of the Northwest Coast culture area (e.g. Suttles, 1990). At contact, the GLCRR was densely occupied. Boyd (1999b, 2013) estimates a population of 15,000 for the entire GLCCR with 55 recorded plankhouse villages (Zenk et al., 2016), of which 21 were in the Wapato Valley and immediate environs. These villages had 154 houses (Hajda, 1984). There are two Lewis and Clark-based population estimates for 17 of those villages (Boyd and Hajda, 1987; Hajda, 1984); a low 
estimate of 3400, and a high estimate of 8040 (Table 1), which is Lewis and Clark's published estimate (see Boyd and Hajda, 1987 for a discussion of these estimates). These high populations were sustained by a very productive environment. The Wapato Valley encompasses the Columbia River, its flood plain, and adjacent upland plateaus. The flood plain contains numerous wetlands, sloughs, ponds, lakes and levees dominated by wetland and riparian vegetation; the rolling uplands by prairies dotted by oak (Quercus sp.) and Douglas fir (Pseudotsuga menziesii) copses. The uplands merged into the foothills of the Cascade Mountains to the east, and the Coast Range to the west, both mantled by the Northwest rainforest (see Butler and Martin, 2013; Ellis, 2013; Gahr, 2013; and Sobel et al., 2013 for detailed discussions of this environment and principle resources).

\section{INSERT TABLE 1 ABOUT HERE}

Two of the houses discussed here are part of the Cathlapotle village archaeological site (45CL1) near Ridgefield, WA (Fig. 3); the third is in the Meier archaeological site (35CO5) (Fig. 4) near Scappoose, OR. Both sites are on the Columbia River floodplain in the greater Portland, ORVancouver, WA metropolitan area. They are about $8 \mathrm{~km}$ apart, albeit separated by the Columbia River. Meier was excavated between 1987 and 1991 by Portland State University's Wapato Valley Archaeological Project (WVAP) under Ames' direction. The site contains remains of at least one plankhouse which was ca. 30 x 14 meters (m), associated middens and "yards", exterior non-midden deposits. The site dates between ca. 950 cal BP (A.D. 1000) and A.D. 1810, but the excavated house is dated between ca 550 cal BP (A.D. 1400) and A.D. 1810 (Ames and Brown, 2018), having a uselife of about 410 years. There is indirect evidence of one or more earlier houses. The house is distinctive for its capacious cellar (Ames et al., 2008) (Fig. 1). Because of the cellar, the house originally had a planked floor, but at some point in the eighteenth century, the cellar was allowed to fill in, and the planked floor replaced by a clay floor. The excavations produced large and rich artifactual assemblages. The excavations and their results are described in Ames et al., 1992; Ames and Henry, 2017a-e; and Smith, 2008.

\section{INSERT FIGURE 2 ABOUT HERE}

WVAP excavated at Cathlapotle from 1991 to 1996, under Ames' direction. Cathlapotle has six large plankhouses in two parallel rows (Fig. 3). The houses are represented on the ground surface by deep depressions. While the entire site was tested, sampling focused on Houses 1 and 4 and their associated middens (Fig. 3). The excavations and their results are described in Ames et al., 1999; Ames and Henry, 2017a - e; Smith, 2008; and Sobel, 2017. House 1 is the largest, its depression is ca $56 \times 10 \mathrm{~m}$, House 4 one of the smaller houses at $12 \times 8 \mathrm{~m}$. Four of the houses were segmented into compartments (smaller houses built end to end). House 1 is one of these; we sampled the three southern compartments (House 1B-D). Except for augering, we did not sample 1A. The Cathlapotle houses also have subfloor storage pit complexes/cellars, but not as elaborate or extensive as Meier's (Ames et al., 2008). These were located beneath sleeping platforms; the houses had earthen floors. Cathlapotle was established ca. 600 cal BP (A.D. 1350) and abandoned in the 1830s. While House 1 was established at ca. A.D. 1350, House 4 appears to have initially built some 60 years later, ca A.D. 1420 (Ames and Brown, 2018). Both were 
probably abandoned when the village was. House 1 had a use-life of some 480 years and House 4 of ca 415 years. Cathlapotle was visited and extensively described by the Lewis and Clark expedition on March 29, 1806 (Moulton, 1991); Meier is not among the 21 historically documented villages in the Wapato Valley.

During excavations, structural features were recorded, and hand-drawn onto maps. Sobel (2017) redrew some of the feature maps in AUTOCAD ${ }^{@}$ and Shepard subsequently redrew and entered all of the structural feature maps and data into ARCGIS ${ }^{\circledR}$. This analysis is based on Shepard's maps (Fig. 5-7), not all of which are reproduced here. They are available in Shepard (2017) as is all of the supporting data.

INSERT FIGURE 3 ABOUT HERE

INSERT FIGURE 4 ABOUT HERE

INSERT FIGURE 5 ABOUT HERE

INSERT FIGURE 6 ABOUT HERE

INSERT FIGURE 7 ABOUT HERE

\section{Political economy, collective action, House societies, labor, household continuity, monumentality, anthropogenic landscapes, property, and the appearance of large houses.}

The political economies of Northwest Coast households are central to research and theorizing on the development of social complexity, including permanent inequality, among what are called transegalitarian, middle-range, or non-state (Stanish, 2017) complex societies. Despite this, and with rare exceptions (e.g. Ames, 1995; Angelbeck, 2017; Grier, 2001; Grier and Kim, 2012; Oberg, 1943), Northwest Coast research is rarely couched in explicitly political economic terms, although it touches on issues of political economy, including the roles of slaves, of high status individuals, and specialists in production and status (e.g. Ames, 1995, 2001, 2008; Burley, 1980; Chatters, 1989; Donald, 1997; Hajda, 2005; Ruyle, 1973); of surplus production and exchange (e.g. Huelsbeck, 1988); of obsidian as a prestige good (Sobel, 2006, 2011); of gender (e.g Moss, 1993, 1999; Pratt, 1999; Walter, 2006); and of property (Grier, 2014; Letham, 2017; Matson, 1985; Trosper, 2009). In the broader anthropological literature, discussions of Northwest Coast political economy often rest on selective and essentialized readings of the region's ethnographic literature (e.g. Johnson and Earle, 2000). Among coastal researchers, the focus overwhelmingly has been on the subsistence economy and its socioeconomic implications (e.g. Ames, 1994, 2005; Angelbeck, 2017; Angelbeck and Cameron, 2014; Butler and Campbell, 2004; Carlson, 1983; Coupland et al., 2001; Donald and Mitchell, 1975; Fladmark, 1975; Matson, 1983; Moss, 2011, 2012; Moss and Cannon, 2011; Schalk, 1977). This results from many factors, including a social syllogism in many traditional Northwest Coast societies in which food $=$ wealth $=$ 
prestige, and a formerly widely held assumption that intensification of salmon production and storage was a, if not the, prime mover in social change on the Northwest Coast and elsewhere in the Pacific Northwest (e.g. Carlson, 1983; Fladmark, 1975; Matson and Coupland, 1995). Interest in the scale and organization of production emphasized the labor required to capture and process salmon for storage and the relationship between high status and the coordination and organization of subsistence production. The assumption of the processual primacy of salmon has been undermined by an explosion of research into the diverse range of subsistence resources constituting the region's resource base (e.g Moss and Cannon, 2011), and on traditional methods to increase resource and patch productivity and stability (e.g. Deur and Turner, 2005). Interest in political economic issues has taken a back seat, with some exceptions (e.g. Grier and Kim, 2012). That results in part from a need for thoughtful assimilation of this new data into discussions of subsistence, and in part to sometimes withering criticisms of the very notions of intensification and social complexity, and their value in Northwest Coast studies (e.g. Moss, 2011, 2012). It is not our purpose here to respond to those criticisms beyond asserting that explaining the evolution of complexity, especially inequality, remains a major task of the social sciences in general and archaeology in particular (e.g. Kintigh et al., 2014), and that political economy is an important theoretical and methodological tool for accomplishing that.

Plankhouse construction offers a window into Northwest Coast political economy complementary to the subsistence economy which illuminates related issues including the temporality of houses, which encompasses the length of their use lives and the stability of their internal architecture as a measure of the stability of the occupying households (Grier, 2006b); the need for environmental management to sustainably supply the wood for these dwellings; the scale of the social networks needed to field labor at crucial junctures; the roles of elites in production; the degree of specialization; and property. Our approach to political economy is best captured by Saitta's definition: "the various and complex ways that humans produce and distribute social labor in specific historical circumstances, and negotiate the cultural conditions that sustain such relationships" (Saitta, 2012). We prefer this definition to those focusing on "financing power strategies" (Earle and Spriggs, 2015, p. 516), which is the traditional emphasis of political economy. While Saitta's definition does not preclude considerations of power, it does not inevitably channel analysis towards power strategies. The more traditional approaches also tend to be top down. While our approach is multi-scalar, its point of initiation is bottom up, in line with household studies' methodology.

This definition helps bridge political economy and collective action theory (e.g. DeMarrais and Earle, 2017) with collective action's interest in non-coercive leadership (e.g. Blanton and Fargher, 2016; Stanish, 2017). Northwest Coast leadership was, in the main, non-coercive, with chiefs having the power to organize, but not power over organizations or individuals (Ames, 1995). Sustained house construction and maintenance over centuries presented Northwest Coast households and communities with long-term collective action problems, as encapsulated in the epigrams opening this paper, and as discussed below.

On the Northwest Coast, Houses sustained collective action. Collective action is simply "a group of people working towards a common goal" (Stanish, 2017, p. 7). However, sustained, long-term collective action is not so simple (see Blanton and Fargher, 2016; Carballo et al., 2012; Stanish, 2017 for thorough treatments of the issues; Thompson et al., 2018 for a relevant 
application). Conflicts between the goals of individuals and of the group are at the root of the problems (Carballo et al., 2012). The common goals typically involve managing resources of some kind where there are "incentives to act selfishly" (Blanton and Fargher, 2016, p. 30) and misuse the resources. To successfully solve this over the long-term, groups must encourage cooperative behavior and deal with free-riders. For Carballo et al. (2017, p. 106-107), this is achieved via the "four Rs": reciprocity, reputation, retribution, and rewards. Blanton and Fargher argue it is achieved through the development of "effective institutions" (2016, p. 40). Stanish (2017, p 6) maintains that sustaining collective action in "complex non-state societies" (those lacking coercive leadership) necessitates "ritualized economies". These are economies in which the cultural norms supporting collective action are inculcated and transmitted across generations via ritual, which may be sacred or secular. Northwest Coast Houses filled this role.

Levi-Strauss' definitions of House societies are sufficiently ambiguous, particularly when coupled with differing translations, to support a literature of exigesis. We use three, Gillespie (2000a, 2000b, 2007) and Marshall (2006), but also see Ames (2006a). Gillespie emphasizes

[T] he maintenance of an estate by a personne morale, a long-lived entity subject to rights and obligations. The "language" of kinship and/or affinity is employed to achieve these twined goals by providing the means to legitimate the intact transfer of the estate across generations of house members. As for the people who must maintain the house, they assume a physical and social place they are given an identity for themselves and a framework for interacting with others - by their membership within or attachment to a house (2000b, p. 27)." The estate includes both the material and non-material wealth managed by the House. On the Northwest Coast, for example, estates could include both resource extraction localities and songs. The House estate ultimately depended on its political economy, which provided the surpluses funding the House's actions (Beck, 2007, p. 6). Levi-Strauss (1983) stressed that Houses were most visible in their interactions with others, and that Houses were both internally and externally hierarchical in those interactions. In contrast, Marshall (2006, p. 38) focuses on the Northwest Coast House defining itself "on the basis of place, particularly residence within a house, while maintaining open and flexible kinship systems and fluid memberships. This reflects the centrality of the physical house manifesting the social House on the Northwest Coast, and that while people came and went, the House persisted. Marshall (2006) stresses that the House defined itself by building, occupying and repairing particular houses in particular places, essentially making and fixing places across time. These places are essential parts of the House estate. The houses were polysemous entities; their interiors materializing both the sociopolitical/spiritual order of the House (e.g. Marshall, 1989 Sobel, 2017), while MacDonald (1983) argues they were cosmograms. Repair and maintenance was thus not just repair and maintenance, but a means by which the internal order of the House could be negotiated, made visible, and replicated or changed. It was also within the House that free rider problems were handled. Thus, while the immediate collective action problems addressed here are the construction and maintenance of plankhouses, the larger collective action problems are the reproduction and perpetuation of the House, and the management of its estate. 
Our route into these issues is estimates of the labor and material costs of plankhouses. Estimating such costs has a long history in anthropology and archaeology and has primarily, but not exclusively (e.g. Morgan et al., 2018), concerned monuments and palaces (e.g. Abrams, 1994; Abrams and Bolland, 1999; Banning, 2011; Erasmus, 1965; Ortmann and Kidder, 2013), rather than domestic or vernacular architecture. While we argue below that Northwest Coast houses are monumental constructions, our initial interest was in the material and labor requirements of Northwest Coast plankhouses during their use lives and how this informed the nature and scope of household production, particularly in terms of the potential role of elites and whether specialists were required (Ames, 1995).

Reconstructing the scale and complexity of house building tasks would suggest the degree to which leadership was necessary. Abrams and Bolland (1999) argue that coordinating leadership is required in major projects only where there are constraints or bottlenecks in the construction process. They assume a generalized or unspecialized labor force. In contrast, Stanish (2017) argues that to be effective such cooperative labor projects require both coordinating leadership and a specialized labor force. While the ethnographic literature of the Northwest Coast sporadically mentions specialization (e.g. Allaire, 1984; Mitchell and Donald, 1988; Oberg, 1943), there has been little archaeological interest in the topic (but see Chatters, 1989). Our own work so far suggests low intensity embedded specialization (Ames, 1995, 2017; Smith, 2008, 2015; Sobel, 2017). As both Oberg and Drucker state in the epigrams introducing this paper, house building on the coast was a major cooperative labor project (e.g. Stanish, 2017) and labor estimates provide a sense of the scales of the project and of the social ties needed for its completion. It is well established that Northwest Coast households were not completely selfsufficient, requiring sometimes extensive networks to access resources (e.g. Suttles, 1960), and to undertake other projects (e.g. Grier et al., 2017) including building houses (e.g. Oberg, 1943). Labor estimates are a means of assessing the cost and the scale of those networks. Network scale includes numbers of people, the area drawn upon (e.g. Stanish et al., 2018), and time or temporality.

Grier (2006a, 2006b; Grier et al., 2017) analyzes the multi-scalar temporal dimensions of households, house building and other such projects under the rubric of temporality. Temporality at the household level encompasses transmission and household reproduction. Temporality for Grier (2006b) is not simply the use-life of a house but is a measure of the occupying household's ability to reproduce itself across generations. His methodology includes establishing the chronology and temporal duration of the house and household. Northwest Coast households theoretically could reproduce themselves organizationally over long periods (Ames, 2006a). Ames showed, using a simple demographic model, that some households could last a millennium. He credited this to a combination of good management, especially of risk, and good luck. Grier measured transmission at the Dionisio Point site in the Salish Sea region by modeling radiocarbon dates and looking at the use of domestic space within the houses through time, as measured by the distribution of tasks. The Wapato Valley Archaeological Project (WVAP) has also done that (e.g. Smith, 2008). Here we analyze the placement of architectural elements through time to measure the architectural stability of the houses as one proxy for the organizational stability of the households. We ask whether the labor we document was fielded by the same household over several centuries. Temporality also encompasses tempo and mode 
(Grier et al., 2017); whether a collective project is done cumulatively over a long period, or whether it is done in short pulses. The quote from Drucker epitomizes both; houses are built in enormous, yet rare bursts of labor, but are maintained over long periods of time by regular, relatively small inputs. created by the same, long-lived House. One consequence of these is monuments.

Scholars increasingly recognize that construction of monuments (e.g. Saunders et al., 1997) and monumental landscapes are not limited to agriculturalists (e.g. Grier and Schwandron, 2017). On the Northwest Coast, there are complex stone alignments (e.g. Supernant, 2017) and defensive works (Angelbeck, 2016; MacDonald, 1984; Moss and Erlandson, 1992), in addition to massive shell middens which represent significant landscape modifications (Grier, 2014; Grier et al., 2017; Letham, 2017; Martindale et al., 2017b). We posit here that Northwest Coast houses and villages (as collections of houses) are monumental constructions. This argument is not new with us, having been made by others (e.g. Grier, 2006a), most forcefully by MacDonald (1983).

Monumentality is often taken simply to mean size, a clear implication of "monumental architecture" as a marker of civilizations (Childe, 1950): civilizations build big things. Northwest Coast houses were the biggest structures on the coast; some many score meters long. However, the question might arise "were they big enough?" to be monumental. Childe (1950, p. 12) also stressed that monumental structures "symbolized the concentration of the social surplus". We show below that, in terms of raw material and labor demands, houses were big enough to qualify as monumental as well as representing a concentrated social surplus. Also, according to the Oxford English Dictionary (OED) (1971) monuments need not be big; they need to be commemorative, of historical significance and enduring. Northwest Coast houses fit those requirements (e.g. Grier, 2006a; Marshall, 2000). However, explicit (e.g. the OED) and implicit to many definitions is a sort of lithocentricism: an expectation that true monuments are only built of stone, not shell or dirt or wood. One need only contrast the different national profiles and heritage management histories of places in the USA such as Pueblo Bonito with its elaborate stone architecture and of Cahokia with its earthen mounds to see this. We show that wooden monuments can be demanding of materials and skill, and they can be enduring over long periods of time. However, their endurance can require a great deal of wood.

The large quantities of wood required by these houses must also have shaped the coast's forests. A major development in Northwest Coast anthropology and archaeology is the realization that the coast's peoples significantly shaped their environment. Various plant management methods are currently the best documented (e.g. Boyd, 1999a; Turner, 2014), but management methods may have extended to both fish and mammals (Campbell and Butler, 2010; Thornton et al., 2015). Researchers are also documenting examples of substantial landesque capital (Håkensson and Widgren, 2014) including intertidal zone plant (Deur, 2002, 2005) and clam gardens (Deur et al., 2015; Grosbeck et al, 2014; Lepofsky et al., 2015; Williams, 2006) and terraformed residential sites (e.g. Grier et al., 2017; Lethan, 2017; Martindale et al., 2017b). A dramatic archaeological example of this management is a 3500 year-old wet land wapato (Sagitarria latifolia) garden near Vancouver, British Columbia (Hoffmann et al., 2016). While many of these anthropogenic environments were no doubt the direct result of intentional human action, others may have been epiphenomena, at least at first. Trant et al. (2016) show that shell middens have a beneficial effect on forest productivity, 
especially that of Western redcedar, a keystone tree in Northwest Coast culture. We argue below that the sheer volume of wood required for plankhouses, among the other uses for cedar, especially over the 6500 years or more that they were built, must have significantly shaped the region's forests and required management for sustainable use over millennia (e.g. Lacourse et al., 2007).

Sustainable resource management has been long recognized as a collective action problem (e.g. Ostrum, 1990). Trosper (2009) argues that property, or proprietorship, formed part of Northwest Coast societies' solution to this problem. This has implications for the development of property concepts on the coast, and by, extension, permanent inequality.

Property has long held a central place in theories of political economy, and it is well documented ethnographically that Northwest Coast households owned estates comprised of both corporeal and non-corporeal property. However, until recently anthropologists and archaeologists have devoted little attention to property since Richardson (1981) surveyed property rules along the coast almost 40 years ago. About the same time, Matson (1985) implicated property in the development of permanent inequality on the coast, but there was little follow-up. Trosper (2009) and Grier (2014) have recently revived property as an issue; Grier built on Gintis' (2007) concept of endowment to argue that concepts of property on the coast grew out of investments in the landscape to increase environmental productivity and in monumentality, ideas that Letham (2017), drawing on Trosper, elaborates. Bettinger (2015) reverses the formula, asserting that concepts of property must exist before such investments are made. In any case, demonstrating the existence of property archaeologically is difficult.

Because political economic thinking among scholars of the coast focuses on subsistence, interest in property focuses on ownership of subsistence resources and resource patches. Except under some extraordinary circumstances (e.g. Wessen, 1988), it is hard to demonstrate that differences in ecofact assemblages among excavated households or sites are a consequence of patterns of ownership and not simply differences in productivity across household catchments. It is also the case that scholars have not looked very hard. The recent thinking on property examines material investments, such as in construction of middens, clam gardens and so on. We extend that thinking to house construction.

Finally, in narratives about the architectural history of the Northwest Coast, the focus is on the social, symbolic and economic implications of the appearance of large houses. The large houses themselves simply appear in archaeological narratives, rather like the Greek goddess Athena emerging fully formed and armored from the brow of Zeus. More broadly, theories and accounts of the origins of sedentism focus on the process and effects of sedentism, with the houses themselves being incidental. But the construction of large plankhouses implies all the aspects outlined above, so their appearance signals significant social and ecological developments in their own right. Different house styles and modes of construction may carry different implications, but building houses has ramifying effects as we detail below.

\section{Methods}

All data, methods, and calculations used to derive the raw material and labor estimates below are presented fully in Shepard 2017. They combine information from the Northwest Coast documentary record, experimental archaeology, and excavation data, some of which is reviewed 
below. A few historical documents and ethnographies provide descriptions of labor tasks related to building and maintaining the dwellings (Boas, 1916; Drucker, 1966; Goddard, 1972; Jewitt, 1987; Koppert, 1930; Niblack, 1970; Stewart, 1984; Wilson, 1866). However, using the Northwest Coast documentary record has its dangers (e.g. Ames, 2006a; Grier, 2007; Moss, 2011). One must be careful to not create what is ultimately a false narrative by blending choice tidbits from here and there. However, the technology employed, and constraints imposed by the raw material and architectural features common along the coast argues that with due care, the documentary record can be employed as we do, especially in tandem with the archaeological record (e.g. Ames, 2008).

Another potential source of information is the plankhouses (a.k.a. longhouses) recently erected by Native groups, universities and other institutions, agencies, and archaeologists. The degree to which these can be used as analogues for traditionally constructed houses is questionable since few are built using traditional techniques and tools. Among these are two Chinook-style plankhouses built in the past 40 years. One was a $3 \times 4.5 \mathrm{~m}$ house constructed on an Oregon State park in 1978 (Fagan, 1985); the second an $11.3 \times 24 \mathrm{~m}$ structure erected on the Ridgefield Wildlife Refuge near Cathlapotle in 2005-2006 (Daehnke, 2007, 2017). Both were built with saw-cut logs. Although construction of the first used traditional tools and construction methods, time and material used are not reported. The second was erected using a mix of traditional and modern methods and tools, and had to meet Federal fire and safety codes. Its construction required 246 cedar logs as well as more than 4000 volunteer hours. However, that total does not include felling and moving the trees or erecting the frame, which was done by machine. It does include splitting and adzing planks, preparing the ground for the house floor, as well as other associated tasks and training.

Archaeological excavations of numerous plankhouses on the southern and central Northwest Coast, including Meier and Cathlapotle, also provide information primarily on architectural feature metrics. The most significant archaeological study of household architecture on the Northwest Coast emerged from the remarkable excavations of Makah plankhouses at the Ozette site on the Olympic Peninsula. The Ozette houses were covered by a mudslide in A.D. 1700 , resulting in excellent preservation of organic material, including wooden architectural features (Mauger, 1978). This allowed researchers to recognize and measure structural elements of buildings, discern how the houses were built, and identify methods of architectural repair. Although some details of house architecture are not applicable to the GLCRR, as houses in the Ozette area were shed-roofed rather than gabled, archaeological data regarding Makah logging and house building techniques provides a rich picture regarding the myriad activities that were involved in building and repairing plankhouses. Other than wet sites and intact houses, direct archaeological evidence of woodworking and wood harvesting activities related to plankhouses is limited. Our primary sources of data are the Meier and Cathlapotle houses.

\section{Building Houses}

\subsection{The House life cycle}

Gahr's (2006) description of the life cycle of Northwest Coast houses frames our discussion. There are three phases: construction, maintenance and demise. 
Construction phase: This phase was triggered by the decision to build a new house. According to Drucker (1966), it was not undertaken lightly. Its duration is difficult to judge, but time was bounded by how pressing was the need to complete the new house which in turn depended on whether it was a replacement for a standing, decaying house or a wholly new house. The phase had social aspects, including negotiations with other households for permission to build and the recruiting and organizing of extra-household labor to erect the house when the time to build came. It also involved the selection and accumulation of raw materials, as well as erecting the house.

Maintenance phase: Once erected, houses needed continual repair because of normal wear and tear, decaying structural members, the occasional fire and other catastrophes. Walls were sometimes moved and interiors reorganized.

Demise phase. At some point the house could no longer be maintained. Gahr (2006) discusses instances of households no longer being able to sustain the costs of upkeep, either through improvidence or poor planning, households breaking up, fire and so forth. In such instances houses might be abandoned, or taken down and replaced; in other instances, new communities were established, thus initiating a new construction phase.

\subsection{Construction phase}

\subsubsection{Raw materials}

Western redcedar was the dominant construction material. They are a large, swiftgrowing, long lived tree, averaging almost $60 \mathrm{~m}$ in height and about $2 \mathrm{~m}$ in diameter at the base (Pojar and MacKinnon, 1994; Waring and Franklin, 1979). They grow best below $1000 \mathrm{~m}$ above sea level, where total annual precipitation is less than $300 \mathrm{~cm}$, and mean annual temperature is between 6-8 $\mathrm{C}^{\circ}$ (Lesher and Henderson, 2010). Although cedars were present in the GLCRR, they probably did not reach their maximum sizes, as conditions are not as favorable as elsewhere on the coast. Cedar was also likely not abundant in the GLCRR. It is rarely the dominant tree species in Northwest Coast forests anywhere, having a patchy distribution (Deur and Turner, 2005, p. 11). In old-growth forests of western Oregon, for example, cedar populations are small compared to those of other trees (Christy and Alverson, 2011; Harrington, 2003; Poage and Tappeiner, 2005, p. 335). The immediate areas surrounding Meier and Cathlapotle were unlikely to have large cedar stands being largely prairie, wetlands and deciduous forests.

Availability of cedar for building materials was also restricted since quality and size of trees varied considerably as did their suitability for building (Gahr, 2006). For example, trees growing in dense stands or close to water are more likely to have knots or low branches (Stewart, 1984, p. 24). Further restricting the availability of cedar was its use for many other technologies, including boxes and the ubiquitous canoes (Ames, 2002). The inner bark was important in a range of technologies including clothing and baskets (Stewart, 1984). Harvesting inner bark alters the growing patterns of trees, which may render them unsuitable for most construction uses. Turner and Davidson (2004, p. 84) observe that "tremendous quantities" of cedar inner bark were harvested on the Northwest Coast. One study of culturally modified cedar trees shows that the majority of trees within specific use areas were subject to inner bark harvesting 
(Lepofsky and Pegg, 1996). Paleoecological research also indicates that selective harvesting depleted cedar stands near village sites on the Northwest Coast (Lacourse et al., 2007), although cedar grows well on abandoned shell middens (Trant et al., 2016).

Despite these issues, cedar is an exemplary building material for house construction: it is easy to work with, splits well, keeps its shape when drying, and resists decay and rot (Stewart, 1984), although it does eventually rot. Cedar is much less prone than are other GLCRR trees to the volumetric shrinkage that can warp and split wood (Countryman and Kemperman, 2000). Although cedar is resistant to warping and decay, it has comparatively low strength when used as posts and beams and has low shock resistance (Forest Products Laboratory, 2010). Using massive posts and beams in houses mitigated this weakness, minimizing the number of times elements had to be replaced, but increasing the labor required to move and work individual logs. The heavy timbers, by virtue of their size, also inhibited burning. Cedar is fire resistant, but extra-large timbers would produce slow burns, rather than conflagrations, although both the Meier house and Cathlapotle House 1 partially burned at least once.

In summary, while using cedar in structures had many benefits, issues existed. Cedar is prone to distortion from weight stress. Small building elements such as planks needed to be replaced frequently because of rot. Furthermore, cedar trees were not unlimited resources; they may have been quite scarce in and around villages, especially considering their high demand for a variety of technologies. As Gahr (2006, p. 65) observes, "[I]n the midst of towering forests, there was a paradoxical scarcity of ideal lumber". Consequently, in some areas, households had property rights in trees and redcedar was evidently managed (Turner 2014, vol 2, p. 184-185).

\subsubsection{Quantities of wood required.}

The amount of lumber used for roof, siding, and floor planks in the Meier and Cathlapotle houses were estimated in board feet (12"x12"x1") based on estimated surface areas of roofs, siding, and floors. Using differing combinations of wall and roof heights yielded a range of possibilities (Table 2). The table's figures should be considered underestimates (Shepard, 2017). For scale, a modern $2400 \mathrm{ft}^{2}$ North American house requires about 16,000 board feet for framing (Idaho Woods Production Commission, 2018).

\section{TABLE 2 ABOUT HERE}

To estimate the amount of material and trees used for post and beams, structural element metrics and counts were used. (Shepard, 2017, Appendix B), since board feet calculations eliminate the curved portions of posts and beams. Meters of circular wood needed for posts and beams was translated into trees required (Table 3). To calculate trees needed for initial construction, meters of posts and beams were combined with board feet needed for planking.

\section{TABLE 3 ABOUT HERE}

\subsubsection{Construction phase labor estimates}


A summary of person days involved in initial construction of plankhouses is difficult. We were unable to quantify many activities; Table 4 contains our best effort. Although this presentation is incomplete and rife with estimations, it is clear from these data that a significant investment of labor was required to obtain materials for and to build houses. A production sequence allows delineation of tasks associated with plankhouse construction and maintenance (see Shepard, 2017 Chapter 6 for detail and sources). We skip many significant expenditures of labor, time and resources, including pre-construction planning, ceremonies and prayers associated with tree felling and construction, as well as costs of recruiting, organizing and deploying workers. Ethnographic and historical accounts demonstrate that these activities required much labor, time and other resources (Gahr, 2006). We also ignore labor spent on tool and equipment (e.g. ropes) manufacturing and repair. Therefore, although the following discussion of materials and construction attempts to be as inclusive as possible, it must be seen only as one part of a larger process.

\section{TABLE 4 ABOUT HERE.}

Planning: We have no basis to estimate the amount of time devoted to planning.

\subsubsection{Procuring Materials}

The first step in obtaining building material was locating and selecting cedar trees of appropriate sizes and quality. It is difficult to quantify the time and effort required searching for and selecting the numerous trees needed for posts, beams and planking. We propose below that houses owned cedar stands, which would have saved some time, but finding suitable trees may have been time consuming because of cedar distribution and growth characteristics, although it is likely locating and monitoring suitable trees was embedded in other forest activities.

Felling trees was next; felling required both effort and skill. Rough estimates of time spent felling trees were calculated based on the experimental archaeology studies (Shepard, 2017, Appendix B) and an eight-hour work day. Koppert (1930, p. 10) implies group size for felling was about 10 people, while Jewitt (1987) writes that 2-3 people were involved in felling. Based on this information, group time spent felling trees for initial construction at Meier was around 19-30 days, at Cathlapotle House 1 it was 24-49 days, and at Cathlapotle House 4 it was 5-10 days, person days were also estimated (Table 4). Importantly, these figures do not account for interior furnishings such as benches. After felling, the trees were stripped of tops, limbs and bark. They were then hauled from the felling location to a watercourse down which logs were floated to the house site. Although precise calculations of time and manpower needed to move logs are not feasible without information regarding terrain and cedar distribution, estimations of weight of the logs represent many metric tons of material and hint at the massive effort entailed in these efforts (Table 5).

\section{TABLE 5 ABOUT HERE}


The labor invested in moving logs is suggested by two sources. Chittenden (1884), reporting on his survey of Haida Gwaii (aka Queen Charlotte Islands), found trails up to two and three miles long constructed for moving cedar logs from the stands. These trails bridged streams and were corduroyed across marshes. Koppert (1930) indicates that moving one large log from the felling site to the water in one day took 60-200 people. This would indicate that significant time was devoted to hauling logs needed for initial construction: 3060-12,600 person days at Meier, 930-4,200 at Cathlapotle House 4 and 4680-20,400 at Cathlapotle House 1. However, because only Koppert provided data regarding moving logs, we decided these numbers were too speculative to include in final labor calculations. However, even if partially accurate, they, taken with Chittenden, demonstrate that transporting logs was a major task associated with house construction and later for house maintenance.

After logs were transported to the water, log drivers guided the logs down the watercourse to the building site. Many coastal villages were located on small islands and so logs needed to be floated or towed across open water. Once the tree arrived at the village's beach, it had to be dragged to the building site. This would likely be accomplished by hundreds of workers pulling the log with strong rope.

Once logs were transported to the village site, they were shaped and adzed. Planks for walls and roofs were split either from large logs using wedges or directly from standing trees, although this was probably rare in the GLCRR. During house construction, systems of ropes, scaffolding and complex levers were used to raise posts and beams. Historical documents attest that amassing requisite material and wealth for house building could take years and that house building entailed "great labor and expense" (Niblack, 1970, p. 374). These methods required not only physical strength, but also a great deal of coordination and planning.

\subsubsection{Preparing Materials}

Both the building site and materials needed to be prepared for building. Prior to construction, the house site was prepared by clearing vegetation, flattening or excavating the house site, and perhaps demolishing the house to be replaced. Along the coast, villages were often, but not always, on shell middens with leveled terraces to accommodate house rows (e.g. Martindale et al., 2017a). In some instances, more extensive terraforming was required (e.g. Letham, 2017). On the northern coast, the interiors of higher status houses were sometimes excavated to create capacious internal spaces one or more levels deep. Post holes and wall trenches were also excavated. The Cathlapotle houses were set into depressions, while the Meier house may have had a shallow depression. Additionally, these houses had deep cellars or storage pit complexes (Ames et al., 2008) which extended at least a meter below the floor of the house. Meier and Cathlapotle are on alluvium; the Cathlapotle depressions and cellars were excavated into a silt-clay; the Meier cellar into an indurated Pleistocene gravel bar. House depression depths of .3 and $2 \mathrm{~m}$ were used to generate labor estimates for the Meier and Cathlapotle excavations (Ames et al., 1999; Hajda, 1994, p. 179; Smith, 2008). Volume of soil moved, and person days required to do so were calculated using morphological information from the two sites as well as data from experimental archaeology (Shepard, 2017). Although estimates encompass wide ranges, they demonstrate that a great deal of labor was needed to excavate the 
underground portion of these plankhouses, pits and corner post holes. At Meier approximately 101-375 person days were needed to excavate soil, at Cathlapotle House 4, 34-104 days, and at Cathlapotle House 1, 116-546 days. Since the Meier and Cathlapotle cellars distinctive features of Wapato Valley houses (Ames et al., 2008), some portion of these labor estimates is not applicable elsewhere on the coast. A great deal of earth moving occurred as the plankhouse itself, any interior excavations, wall trenches, and postholes were all excavated.

Other crucial tasks including preparing frame members (e.g. notching posts), and splitting and adzing planks. Post, beams and many planks were adzed. Mauger (1978) reports that half of all planks at Ozette were adzed, including all roof and bench planks. Adzing is the final step in finishing wood surfaces, analogous to sanding. A small adz is used to trim long, shallow flutes lengthwise along the object. Considering the large number of planks, posts and beams needed for construction, this would represent a considerable output of time and labor. The effort at the Ridgefield plankhouse, provides a sense of this; some 420 person days were invested in splitting and adzing planks, and shaping posts and rafters, using a mix of traditional and modern equipment and methods. Not all planks were adzed.

\subsubsection{Construction}

Our understanding of house raising techniques is mainly based on accounts from the northern and central Northwest Coast. Still, this information provides important clues to how inhabitants of Meier and Cathlapotle may have accomplished the substantial task of house construction (e.g. Stewart, 1984). Raising the massive corner posts, eave supports, and ridge supports entailed the efforts of large numbers of people. Gahr (2006) uses two historical accounts of house construction to calculate the number of people needed to erect one dwelling in a single day (Table 6), the practice on some parts of the coast, but seemingly not in the GLCRR. However, the estimates give a sense of the scale of the task and of the cooperative labor pool needed to accomplish it. These can be taken as maximal estimates of the cooperative labor pool. She estimates that one person is needed for every $0.19-0.33 \mathrm{~m}^{2}$ of house area. Revised household population estimates based on a floor area/person index for Cathlapotle (Ames, 2008) suggests manpower needs 7 to 12 times greater than household populations (Table 1). Table 6 places Gahr's estimates in context using Lewis and Clark's low and high population estimates for the Wapato Valley (Table 1). While erecting House 4 would have required a majority of the entire Cathlapotle village, House 1 and Meier would draw upon a significant portion of the regional population.

The question arising from this is what are the labor demands if longer than a day in taken to build the house? We answer that question by dividing the median person days for building each house (Table 4) by some proportion of the house populations (Table 1) since not all house members will be involved in house construction. We use Cook's ratio of 1:4 for estimating the proportion of men in North American Native populations between the ages of 15 and 50 (Cook, 1976a, 1976b). It is quite likely that both women and men were members of house building work groups; Cook's ratio is simply a means to make an estimate. Using that ratio, a minimum estimate for Meier is a team of 50 taking 42 (eight-hour) days; Cathlapotle House 1 a team of 38 taking 91 days, and House 4 a team of 10 taking 64 days. We regard these estimates with some 
skepticism. Our estimates (Table 4) do not include all tasks, especially moving logs, which took considerable labor, nor splitting and adzing. The size of the needed labor pool would depend on how much time was available to build the house, but, over and above that, certain tasks, such as moving logs, called upon labor beyond the house (e.g. Vastokas, 1966). It is quite unlikely, for example, that 10 people would be enough for the major tasks associated with erecting even a small house such as House 4, which is actually a fairly typical Northwest Coast house in size (Ames, 1996). Finally, as we discuss below, while it is likely that even small households such as House 4 might possess house building/repairing skills, they are unlikely to have had the needed specialists. Thus, while Gahr's figures provide a maximum labor pool estimate, we think they provide a better sense of the needed labor pool than do these minimums.

TABLE 6 ABOUT HERE

\subsection{Maintenance Phase}

At Meier and Cathlapotle, as with many Northwest Coast villages, houses stood for centuries, requiring continual inputs of labor and building materials. At Ozette, many planks bear signs of mending and recycling (Mauger, 1978, p. 92-96). The effort invested in repairing and reusing rather than replacing planks suggests obtaining new ones was difficult and time consuming. Standing remains of a mid- $19^{\text {th }}$ century Nuu-chah-nulth plankhouse provides additional data on repair (Smith et al., 2005). Beams not exposed to the ground were in relatively good condition compared to elements in the soil. Corner posts had considerable rot, and building elements needed to be replaced more frequently if they contacted the ground or bore a heavy load. Cutting dates based on dendrochronology suggest elements were continually replaced as they became structurally unsound. In addition to on-going maintenance, there was sometimes need for significant repair and renovation. Cathlapotle Houses 1 and 4 were repaired after suffering major flood damage (Hodges, 2017) and Meier and House 4 had walls moved. Meier and Cathlapotle House 1 each partially burned at least once.

Gahr (2006, p. 73) considers many aspects of plankhouse repair in her analysis of the plankhouse-life cycle, and stresses an "enduring commitment of labor and materials" was required. She outlines the stresses placed on wood elements, including load, creep, high winds, earthquakes, hydraulic pressure, fire, and biological decay organisms. Ames et al. (1992) use excavation data to estimate that each Meier house element, depending on its size, would need to be replaced at a minimum of 5 times over the house's 400 year use-life, and probably closer to 20 times. Shepard (2017) increased the precisions of those estimates by applying information from forestry studies to data from features at Meier and Cathlapotle to estimate replacement rates. We estimate that a plank with base dimensions of $40 \mathrm{~cm} \times 7.6 \mathrm{~cm}$ would need to be replaced every 20 years. This figure was used to approximate planking material needed over the houses' existence (Table 7).

\section{TABLE 7 ABOUT HERE}

We also estimate material needed for post replacement, although rates of post replacement were more difficult to determine. It is likely that deteriorating posts would be 
monitored and quickly replaced, as failure in posts and beams (unlike wall planks) could be catastrophic. We used this calculation to approximate the number of trees used over each house's lifespan for repairs, 400 years for Meier and Cathlapotle House 4, and 454 years for Cathlapotle House 1. These calculations yielded a large total number of trees needed for repairs of planks, posts and beams ranging from hundreds of trees for a smaller house to a number potentially approaching 1500 trees for a larger house (Table 8). The annual demand for logs was not high, but the cumulative effect was, and it was ongoing.

\section{TABLE 8 ABOUT HERE}

Replacing these elements would entail considerable effort and skill in addition to locating, felling and transporting trees for new posts and planks. Removing and replacing a rotting post from a standing structure is, for example, a difficult task (Reynolds, 1995). The mechanics of replacing a corner post or ridge beam in an inhabited plankhouse would have been challenging. Since the largest posts and beams were likely replaced infrequently, these events may have occurred only about once a generation. Thus, people with knowledge of the mechanics of this operation - building specialists - might have been relatively rare in any given house, but needed regularly through-out the valley. It is important to note that in addition to repairs associated with architecture, a number of other activities were necessary for upkeep. Houses at both Meier and Cathlapotle included massive pit complexes, which were constantly re-dug, especially since they were in an active flood zone. Hearths were continually maintained and cleaned (see Gardner-O'Kearny, 2017). Other ongoing house activities would include sweeping and refuse disposal. Taken together, obtaining and preparing raw materials, repairing wooden elements, and sundry house upkeep tasks would have required an enormous expenditure and variety of different types of labor.

\subsection{Demise Phase}

The Meier and Cathlapotle houses were vacated as a result of Euroamerican contact, most likely of the introduced epidemic diseases which decimated the Native population of the GLCRR between the 1770s and the 1830s (Boyd, 2013). Thus there was no demise phase in Gahr's sense (Gahr, 2006). It is possible, in the absence of colonialism and diseases, these houses and households may have persisted for many more years.

\section{Structural Continuity.}

We use structural continuity as a proxy for the temporal stability of the households occupying these houses, that all of this cumulative labor was fielded by the same, long-lived social entities. Since household groups were inextricably linked to plankhouses, change in the physical house structure would indicate possible shifts in social organization. Structural continuity was measured in three ways: The degree to which structural elements had similar vertical, and horizontal positions through time, and the compass orientations of plankmolds (Shepard, 2017). These analyses were based on fine scale maps. Structural elements generally retained their vertical and horizontal positioning through time in the houses. Conservation of element placement was especially strong in central house areas. The maps did pinpoint several 
spots in all three houses where element elevation changed in house walls. The most variation in vertical positioning of elements seems to have occurred in Cathlapotle House 4, where it is possible the house underwent a significant change in length during its lifespan. The Meier house also may have been substantially altered, as evidenced from a wall trench placement indicating that the house was shortened by at least one meter. Its long axis also shifted slightly early in its uselife and a major hearth at its south end was either shifted or expanded midway through the house's use-life (Ames et al., 1992). Plankmold orientations also indicate house structural continuity, although these results were affected by small sample size and possible outliers, which may have inhibited detection of trends. But there are no clear instances of shifting house orientations over time. Overall, evidence of changing house attributes is the exception rather than the norm. Despite some minor modifications, houses were overall remarkably stable in structural appearance over the centuries and many generations, even in the face of fire and flood (see above).

Results of this project strengthen previous assessments (Ames et al., 1992; Smith, 2008) that these households maintained remarkable continuity over hundreds of years. Importantly, this continuity does not reflect stasis in the community as a whole. Rather, household stability persisted in light of climatic and environmental shifts (e.g. Grove, 1988, p. 231-239) as well as demographic, economic and technological changes in the protohistoric period (Ames, 2017; Ames and Brown, 2018; Boyd, 1999b; Lightfoot, 2006). Remarkable stability in the midst of other changes demonstrates that much value was afforded to and effort was directed towards sustaining household continuity.

\section{Discussion}

\subsection{Political economy and social scale}

Plankhouse construction and maintenance were complex, demanding tasks, the labor requirements for which often exceeded the capacities of a single household. While the houses were invested with multiple symbolic meanings, at a minimum they represented a household's capacity to field and manage considerable labor and material. They also tangibly represented the scale of the household's social networks since much of the labor, as our estimates show, had to be recruited well beyond the household. Construction of Cathlapotle House 1, and of Meier, may have called upon a significant portion of the regional population. Cathlapotle House 4, on the other hand, was within the capacity of the Cathlapotle village to build. Since these networks were based on reciprocal relationships, houses also embodied the household's obligation to, if nothing else, participate in other house raisings. It is also likely, for reasons discussed below, that households building a house would need to call on others for logs.

It is unlikely this labor was the generalized, unskilled labor envisioned by Erasmus (1965), and Abrams and Bolland (1999); rather we envision it to be the specialized labor described by Stanish (2017). However, we distinguish between skilled and specialized labor. Our conception of skilled labor is that most people are competent in the basic skill sets needed to function well in a particular technology/economy. This accords, for example, with Turner's (2014) description of the knowledge needed to tend and harvest plants being widespread among

First Nations people, i.e. it was a skill. Our data for Meier and Cathlapotle show that essentially all technological and production activities occurred throughout all the houses (Ames, 2017; 
Smith, 2008, 2015). For example, all household segments hunted terrestrial mammals. However, overlying that was a degree of specialization or at least occupational emphases. Thus, mammal hunting was a particular focus in the southern portions of Cathlapotle House 1 and Meier, while there is no such focus in House 4. We hypothesize that similarly the basic skills needed to build a house were widely shared, but that there were certain skills that were more efficiently deployed through embedded specialization (Ames, 1995) or which required considerable time and energy to acquire. Turner (2014, Vol. 1, 33), for example, observes that people were vigilant about how cedar was harvested, and close attention was paid to "ecological and genetic diversity and spatial variation in populations." This knowledge would be critical for knowing which stands had timber suitable for house construction, which for making canoes, and which for bark harvesting. Expertise in selecting suitable trees beyond this base knowledge would likely be highly prized, given the costs of selecting the wrong tree, in the same way and for the same reasons that expertise in canoe making was highly prized - the high cost of failure (Ames, 2002).

We suspect house-building expertise was available at the regional level, but not necessarily at the household level. Basic house building skills were no doubt well dispersed through the broader community. While each of these three houses were built only once in almost a half-millennium, the Lewis and Clark census (Hajda, 1984) enumerates 154 houses in the Wapato Valley in 1806, some smaller than those analyzed, some much larger, as much as $123 \mathrm{~m}$ long. Given that, it is certain that houses were constantly being built and repaired across the valley. Thus basic house building skills had to be common, being called upon somewhere in the valley regularly, although perhaps not regularly in any given household. However, given the volume of materials, the complexity of the tasks, the numbers of people involved, and the need for coordination, expertise beyond basic skills would be necessary. Given that these were ongoing, never ending tasks, specialists are likely, especially given the life span of these houses. Whether this coordination was a task of the household's elite, or construction specialists (or both), we don't know, although it seems likely to have been the job of members of the elite (Ames, 1995) as was pulling in and holding the labor (but see Vastokas, 1966). One of the roles of the GLCCR elites was the cultivation of social ties, sometimes across long distances (Hajda, 1984). Finally, and simply restating much of the foregoing, house building shows how the political economy of some Northwest Coast households extended well beyond the individual household, encompassing significant portions of their region.

\subsection{Anthropogenic environments}

Considerable attention has been paid to Native management and shaping of Northwest Coast environments (e.g Deur and Turner, 2005). In this literature, ownership and management of cedar stands is mentioned (e.g. Blukis Onat, 2002; Turner, 2014), but, to our knowledge, is nowhere elaborated. We argue that the timber requirements of house construction both shaped cedar stands, and necessitated some form of management, including ownership. House construction obviously required large numbers of logs. Using the median estimates for the number of logs represented by Cathlapotle Houses 1 and 4, the 154 Wapato Valley houses would have required some 3000 to 14,000 trees (Table 3) to build. House repair cumulatively also demanded large numbers of trees, although not on an annual basis for individual structures (Table 8). However, ongoing repair of 154 houses would annually require between 150 and 600 
logs. We argue these demands obliged household ownership of cedar stands to ensure access to trees as needed, coupled with forms of cedar silviculture for managing stands to ensure a sustainable supply of appropriately sized and shaped trees. Given the needs for cedar not only for houses, but for ubiquitous and numerous canoes (Ames, 2002), carvings, baskets and other items, it seems highly unlikely that finding appropriate trees was left to chance, particularly in light of the relative rarity of cedar trees (see above) and of the very well documented management of other plants and habitats (e.g. Turner, 2014). Ownership and management of trees and stands would be crucial to sustained use, especially over millennia. One reviewer of this paper raised the possibility of a trade in cedar logs, similar perhaps to the trade in canoe hulls (Ames, 2002) that would have eased potential shortages in logs. While an important possibility, it seems unlikely that would solve the problems of access and sustained use. He also suggested that we overestimate the use of cedar in building these houses, that too is an important possibility, but it does not, to us, reduce the need for an active syliculture. In any case, it is likely that cedars were managed as a "common pool resource" (Ostrom, 1990), that is resources that "generate finite quantities of resource units and one person's use subtracts from the quantity of resource units available to others (Ostrum, 2000, p. 29-30)" with long-term sustainable use the management goal. Defining who has exclusive rights to the resources is fundamental to its management (Ostrom, 2000, Table 1; Trosper 2002). On the Northwest Coast, such rights were usually vested in the household. However, it seems likely that an adequate long-term supply of logs depended on reciprocal ties, especially when a house was built, or major renovations undertaken. It could be argued that managing cedars would be difficult because they are a very long-lived tree. However, cedars are a relatively fast-growing tree, and management no doubt involved shaping the habitat to encourage desired growth characteristics (Blukis Onat, 2002). Still, the temporal horizon of management strategies was certainly decades, if not centuries.

\subsection{Property}

It is well documented ethnographically that households owned both the structure of their houses and the ground on which they stood. One could argue alternatively that this ownership is a consequence of the enormous investment the houses represent, or that the investment is a consequence of ownership (e.g. Bettinger, 2015). Grier (2014) has recently posited that the property rights along the coast developed hand in hand with environmental management practices. For our purposes, these are chicken-egg arguments. We propose that the presence of these houses, especially those too large for the household itself to build, is prima facie evidence for the existence of property rights, both because of the expense of the houses themselves and because their persistence over millennia minimally required ownership and management of cedar stands. Thus, we argue property rights existed on the northern Northwest Coast by $3500 \mathrm{cal} \mathrm{BP}$, with the presence of multi-house villages with large houses, and on the southern coast by 3500 cal BP with the presence of large post and beam houses.

\subsection{Continuity}

Our analyses support Drucker's claim that Nuu-Chah-Nulth houses essentially stood from time immemorial. The three Chinookan structures examined in this study stood for 400 or more 
years and were abandoned only when their households were swept away by epidemics Otherwise, these houses and households could have persisted much longer. During those 400 plus years, exterior walls were occasionally shifted and in one case (Meier) interior arrangements altered, but the basic frameworks and interior organization of the houses remained unchanged through the on-going replacement of posts and planks. This indicates the durability of both the houses and the occupying Houses. Ames (2006b) suggests that some houses on the coast could persist for a millennium and explores the implication of that. Not all houses were occupied this long. House 2 at the well-documented village of Dionisio Point in the Salish Sea of southwestern British Columbia was occupied for perhaps 200 years (Grier, 2006b), and the coast's archaeological record is replete with abandoned houses and villages. However, given the investment houses and villages represented and the potential long use-life of houses, a decision to abandon was likely just as serious as the decision to build a house.

Continuity extends beyond a particular house. Along much of the Northwest Coast, the interior layouts of houses remained consistent across at least three millennia and some villages were occupied for at least that long if not much longer. The houses in the 2000 year old village near Cathlapotle had the same interior arrangements as the Meier and Cathlapotle houses (Ames et al., 2008).

\subsection{Appearance of houses}

Archaeological narratives generally speak casually of the first appearance of houses, including large houses. Some houses do represent small investments (e.g. Ellis, 2006), but others require large investments in material and labor well beyond the capacity of the household itself. Large wooden houses, and other wooden structures, also bring in their train other requirements, such as forestry management and control. We do not imply all these things must be in place before large houses could be built, but rather they must develop for the practice to persist. The same sorts of organizational questions need to be asked about the appearance of labor-intensive houses as are being asked about, for example, the construction of large earthen mounds in the Southeastern United States (e.g. Kidder, 2011).

\subsection{Monumentality}

Archaeological discussions of monumentality inevitably focus on presently visible monuments or ruins, particularly those of stone. We have a strong tendency to privilege stone, even easily worked limestone, over earth, shell or wooden monuments such as wood henges; these are essentially invisible, unless they are still standing and actively maintained as are certain ancient Japanese wooden temples. Otherwise, they rot away, and can be archaeologically invisible, save for some exceptional circumstances, such as the Ozette site. In some instances, the disappearance was intentional. Northwest Coast commemorative ("totem") poles were expected to eventually fall, rot, and disappear, to be replaced with another. As a consequence, we argue, assessments of monumentality tend to ignore or underplay wooden structures, especially domestic ones.

Scholars recognize monuments along at least a couple of dimensions. One, following the OED, is that they be commemorative, of historical significance and enduring. The other is that they represent a great deal of effort and skill; in other words, they have to be monumental. We 
have documented the effort and skill invested in Northwest Coast plankhouses in this paper, i.e. their monumentality. However, to reinforce the point, it is useful to compare Northwest Coast houses with monumental stone monuments generally attributed to hunter-gatherers, in this case those at the Anatolian Prepottery Neolithic (PPN) site of Gobekli Tepe. The site is located in south central Turkey and is famous for its symmetrical arrangements of massive, T-shaped limestone monoliths, the most firmly dated examples of which date to ca. $7500 \mathrm{BC}$ (Banning, 2011). The monoliths are incorporated in oval structures about 10x15m in size (Banning, 2011). The excavator, Klaus Schmdt (Banning, 2011; Schmidt, 1998), interprets them as open-air temples while Banning suggests they may be houses, albeit symbolically rich ones. The monoliths are well carved and many bear sculpted images. Banning estimates low and high mass or weight ranges of five of them, which range from 740 to $10,800 \mathrm{~kg}$ (Banning, 2011, Table 1) with a median (including both low and high mass estimates) of $5450 \mathrm{~kg}$, or about 5.5 metric tons, which he estimates would require $14-17$ people to move from the nearby quarry to the building site. At 5.5 metric tons, the wood in the Meier house is equivalent to between 6 and 15 monoliths, depending on whether the house was floored or not, Cathlapotle House 4 to 2 - 5 monoliths and House 1 to 11 - 25 monoliths (remembering our estimates do not include House 1A). The structures illustrated by Banning (Banning, 2011, Figures 2 and 3) have as few as one monolith and as many as 14. Banning's labor estimates do not include preparation of the site, construction of the circumferential walls nor the roofs in his house reconstructions, or the total labor invested in all of the Gobekli Tepe monoliths, so his estimates are minimums. However, a reasonable conclusion is that the costs for the Meier and Cathlapotle houses are at least equivalent to the costs of the individual Gobekli Tepe structures in labor, skill and coordination. They were also equivalent in symbolic content; we know the interiors of Chinookan houses, like all Northwest Coast houses, were spiritually charged; large houses at least had richly carved and painted interiors and were the venues for both quotidian and ceremonial activities. Indeed, Banning uses Northwest Coast houses to illustrate symbolically charged and costly domestic structures. One major difference is that Northwest Coast houses were made of western redcedar and the Gobekli Tepe monuments were of limestone. A second difference is that standing stone monuments do not require the constant input of effort that do wooden ones, effort which would be a continual reminder and renewal of the monument's meaning. A third difference is that once maintenance ceases, wooden monuments rapidly disappear, while stone ones can last millennia.

\subsection{Final comments}

We warned above against creating false essentialized narratives about the Northwest Coast by weaving together tidbits of information from here and there. How broadly applicable are our results? Our sample is small, three houses on the Lower Columbia River; the Northwest Coast vast, some $1800 \mathrm{~km}$ long. House styles and construction details varied along the coast, which would affect estimates such as ours. Ownership practices varied; in parts of the Salish Sea, for example, individual families owned their planks and took them with them if they shifted Houses (Suttles, 1991). However, a number of our conclusions can be safely generalized. Among them are: constructing these houses required significant amounts of material and labor, however apportioned and, irrespective of architectural differences among house styles. The houses were much more similar than they were different. All documentary sources of which we are aware 
comment that large numbers of people were required to construct houses. That labor needed to be skilled and some of it specialized. House construction and repair would have significantly impacted local and regional forests, requiring long-term sylvicultural and stand ownership to ensure sustainability. We also suggest our results can be generalized beyond the Northwest Coast, even where wooden structures were not maintained across centuries. For example, hundreds if not thousands of longhouses were built using oak for structural members across Europe during the Linear Bandkeramik (ca 5500-4900 cal BC) and apparently occupied for periods as short as 20 years (Courdat, 2015, papers in Hoffmann and Smyth, 2013). This must surely have affected European forests while the regular shifting and building of new houses imposed collective action problems on Bandkeramik societies. A second example are Cherokee townhouses which were widespread across the southern Appalachian Mountains of the American Southeast (Rodning, 2006, 2009) from the $15^{\text {th }}$ to $18^{\text {th }}$ centuries AD. Townhouses were large wooden public structures central to Cherokee life, fulfilling many of the roles as did plankhouses for Northwest coast societies, including place-making. However, townhouses were regularly destroyed and rebuilt. Rodning (2009) documents six such structures being built at one site during a century or so. This practice again raises issues around collective action and forest management.

\section{Conclusions}

Household archaeology tends to overlook the building of houses, emphasizing household functions, and households as social process, with house architecture as both reflecting and shaping those processes. However, building and maintaining houses can provide access into the political economies of households, with ramifications well beyond the individual household, as we have shown here for three southern Northwest Coast houses, focusing on material and labor costs. These led us to a range of implications, including collective action; the control and flow of raw materials for house construction; anthropogenic environments; the potential role of elites; generalized, skilled and specialized labor, and the regional scale of pools of labor and skills; large houses as evidence for the existence of property; the long-term social and cultural continuity reflected by these long-lived structures; and the appearance of houses in the archaeological record potentially bringing all of these topics in their train - houses don't just appear. Furthermore, we have argued that Northwest Coast houses should be viewed as monumental architecture and wooden monuments vis a vis stone monuments.

Northwest Coast archaeologists have emphasized subsistence economy both in considerations of what we are calling political economy, but as also a driver of social and economic change on the coast, especially in the development of social complexity, including inequality. They have also focused on the large Northwest Coast household as a central actor in those developments, household size often being attributed to the labor demands of the subsistence economy (e.g. Ames and Maschner, 1999) and as a marker of social inequality. Our analysis is complementary to those approaches by showing what is required to live in a massive wooden house that may stand for centuries. It also shows that the development of sedentism and moving into permanent houses may not be a simple matter of building houses. For the pattern to persist, house building techniques and skills need to be developed and refined, and a political economy evolved that goes beyond putting up stores to the complex tasks of managing the 
growth and acquisition of raw materials for houses. Finally, the archaeological record of house construction at Meier and Cathlapotle shows that Drucker and Oberg were spot on in their descriptions of what Northwest Coast house construction and maintenance entailed, but perhaps even more then they, fine ethnographers that they were, understood, 


\section{Acknowledgements.}

The research reported here was conducted as part of Portland State University's Wapato Valley Archaeological Project. We want to acknowledge and thank the Chinook Indian Nation for their sustained engagement with the Cathlapotle project and the Confederated Tribes of Grand Ronde for their support of both the Meier and Cathlapotle excavations. We particularly thank Gary and Tony Johnson, former and current Chairs, Chinook Tribal Council for their interest and support of the project. Anan Raymond, United States Fish and Wildlife Service Regional Archaeologist has supported the project through thick and thin. Nancy Turner shared important yet obscure sources. We also thank her for her seminal work on Pacific Northwest ethnobotany and anthropogenic landscapes. Yvonne Marshall and Colin Grier also tracked down sources for us. Our thinking for this paper benefited from conversations with Ann Gahr, Bryn Letham, and Andrew Martindale. Colin Grier and Victor Thompson materially improved it with their comments. We are, of course, responsible for any and all errors.

Funding Sources. This work was supported by Portland State University, the United States Fish and Wildlife Service, National Endowment for the Humanities Grant RZ-50601-06, the Jean and Ray Auel Foundation, and the Research Institute for Humans and Nature (Japan).

Declaration of Interest: None. 


\section{References Cited}

Abrams, E.M., 1994. How the Maya Built their World. University of Texas Press, Austin.

Abrams, E.M., Bolland, T.W., 1999. Architectural energetics, ancient monuments, and operations management. Journal of Archaeological Method and Theory, 6, 263-290.

Allaire, L., 1984. A native mental map of Coast Tsimshian villages. In: Seguin, M. (Ed.), The Tsimshian: Images of the Past, Views for the Present. The University of British Columbia Press, Vancouver, pp. 82-98.

Ames, K.M., 1981. The evolution of social ranking on the Northwest Coast of North America. American Antiquity 46, 789-805.

Ames, K.M., 1994. The Northwest Coast: complex hunter-gatherers, ecology, and social evolution. Annual Review of Anthropology 23, 209-229.

Ames, K.M., 1995. Chiefly power and household production on the Northwest Coast. In: Price, T.D., Feinman, G.M. (Eds.), Foundations of Inequality. Plenum Press, New York, pp. 155-187.

Ames, K.M., 1996. Life in the big house: household labor and dwelling size on the Northwest Coast. In: Coupland, G., Banning, E.B. (Eds.), People Who Lived in Big Houses: Archaeological Perspectives on Large Domestic Structures. Prehistory Press, Madison, pp. 131-150.

Ames, K.M., 2001. Slaves, chiefs and labour on the northern Northwest Coast. World Archaeology 33, 1-17.

Ames, K.M., 2002. Going by boat: the forager-collector continuum at sea. In: Fitzhugh, B., Habu, J. (Eds.), Beyond Foraging and Collecting: Evolutionary Change in Hunter-Gatherer Settlement Systems. Kluwer/Plenum Press, New York, pp. 17-50.

Ames, K.M., 2005. Intensification of food production on the Northwest Coast and elsewhere. In: Deur, D., Turner, N.J. (Eds.), Keeping It Living: Traditions of Plant Use and Cultivation on the Northwest Coast of North America. University of Washington Press, Seattle, pp. 67-101.

Ames, K.M., 2006a. Thinking about household archaeology on the Northwest Coast and elsewhere. In: Sobel, E.A., Gahr, D.A.T., Ames, K.M. (Eds.), Household Archaeology on the Northwest Coast. International Monographs in Prehistory, Archaeological Series 16., Ann Arbor, pp. 16-36.

Ames, K.M., 2006b. The place of Ozette in Northwest Coast archaeology. In: Welchel, D.L. (Ed.), Ozette Archaeological Project Research Reports Volume III: Ethnobotany and Wood Technology. Department of Anthropology Reports of Investigations 68. Washington State University, Pullman, pp. 9-24. 
Ames, K.M., 2008. Slavery, household production and demography on the Southern Northwest Coast: cables, tacking and ropewalks. In: Cameron, C.M. (Ed.), Invisible Citizens: Captives and their Consequences. University of Utah Press, Salt Lake City, pp. 138-158.

Ames, K.M., 2017. Postscript to artifact classification, descriptions, and analyses of artifacts from the Cathlapotle and Meier archaeological sites, Lower Columbia River: lithic technology, projectile points, and osseous artifacts. In: Ames, K.M., Henry, K. (Eds.), Artifact Classification, Descriptions, and Analyses of Artifacts from the Cathlapotle and Meier Archaeological Sites, Lower Columbia River: Lithic Technology, Projectile Points, and Osseous Artifacts. Wapato Valley Archaeological Project Report \#11

Portland State University/U.S. Fish and Wildlife Service, Portland, pp. 435-470.

Ames, K.M., Brown, T.J. 2018. Radiocarbon dating the fur trade: Bayesian analyses of FurTrade Era radiocarbon dates from the Lower Columbia River. International Journal of Historical Archaeology. https://doi.org/10.1007/s10761-018-0466-1

Ames, K.M., Henry, K., 2017a. Architecture, Fire, and Storage: Cathlapotle and Meier Features. Wapato Valley Archaeological Project Report \#9. State University/U.S. Fish and Wildlife Service, Portland.

Ames, K.M., Henry, K., 2017b. The Fur-Trade Archaeology of the Cathlapotle and Meier Sites, Lower Columbia River. Wapato Valley Archaeology Project Report \#10. Portland State University/U.S. Fish and Wildlife Service, Portland.

Ames, K.M., Henry, K., 2017c. Lithic Technology, Projectile Points, Osseous Artifacts, and Artifact Classification of the Cathlapotle and Meier Archaeological Sites, Lower Columbia River. Wapato Valley Archaeology Project Report \#11. Portland State University/U.S. Fish and Wildlife Service, Portland.

Ames, K.M., Henry, K., 2017d. The Zooarchaeology of the Cathlapotle and Meier Archaeological Sites, Lower Columbia River. Wapato Valley Archaeological Project Report \#12. Portland State University/U.S. Fish and Wildlife Service, Portland.

Ames, K.M., Henry, K., 2017e. Geoarchaeology and Miscellaneous Reports: Cathlapotle and Meier Archaeological Sites, Lower Columbia River. Wapato Valley Archaeology Project Report \#13. Portland State University/U.S. Fish and Wildlife Service, Portland.

Ames, K.M., Maschner, H.D.G., 1999. Peoples of the Northwest Coast: Their Archaeology and Prehistory. Thames and Hudson Ltd., London.

Ames, K.M., Raetz, D.F., Hamilton, S.C., McAfee, C., 1992. Household archaeology of a Southern Northwest Coast plank house. Journal of Field Archaeology 19, 275-290.

Ames, K.M., Smith, C.M., Bourdeau, A., 2008. Large domestic pits on the Northwest Coast of North America. Journal of Field Archaeology 33, 3-18. 
Ames, K.M., Smith, C.M., Cornett, W.L., Sobel, E.A., Hamilton, S.C., Wolf, J., Raetz, D., 1999. Archaeological Investigations at 45CL1 (1991 -1996) Ridgefield Wildlife Refuge, Clark County, Washington: A Preliminary Report. U.S. Department of the Interior, Fish and Wildlife Service Region 1, Portland, Or.

Ames, K.M., Sobel, E.A., 2013. Houses and Households. In: Boyd, R.T., Ames, K.M., Johnson, T.A. (Eds.), Chinookan Peoples of the Lower Columbia. University of Washington Press, Seattle, pp. 125-145.

Angelbeck, B., 2016. The balance of autonomy and alliance in anarchic societies: the organization of defences in the Coast Salish past. World Archaeology 48, 51-69.

Angelbeck, B., 2017. Applying modes of production analysis to non-state, or anarchic, societies: shifting from Historical Epochs to seasonal microscale. In: Rosenswig, R.M., Cunningham, J.J. (Eds.), Modes of Production and Archaeology. University Press of Florida, Gainesville, pp. 5274.

Angelbeck, B., Cameron, I., 2014. The Faustian bargain of technological change: evaluating the socioeconomic effects of the bow and arrow transition in the Coast Salish past. Journal of Anthropological Archaeology 36, 93-109.

Archer, D., 2001. Village patterns and the emergence of ranked society in the Prince Rupert Area. In: Cybulski, J. (Ed.), Perspectives on Northern Northwest Coast Prehistory. Archaeology Survey of Canada, Canadian Museum of Civilization, Ottawa.

Banning, E.B., 2011. So fair a house: Göbekli Tepe and the identification of temples in the PrePottery Neolithic of the Near East. Current Anthropology 52, 619-660.

Beck Jr, R.A., 2007. The durable house: material, metaphor, and structure. In: Beck R.A. Jr. (Ed.), The Durable House: House Society Models in Archaeology. Occasional Paper No. 35. Center for Archaeological Investigation, Southern Illinois University, Carbondale, pp. 3-24.

Bettinger, R.L., 2015. Orderly Anarchy: Sociopolitical Evolution in Aboriginal California. University of California Press, Berkeley.

Blanton, R.E., 1994. Houses and Households: A Comparative Study. Plenum Press, New York.

Blanton, R.E., Fargher, L.F., 2016. How humans cooperate: Confronting the challenges of collective action. University Press of Colorado, Boulder.

Blukis Onat, A. 2002. Resource cultivation on the Northwest Coast of North America. Journal of Northwest Anthropology 36, 125-144.

Boas, F., 1916. Tsimshian Ethnography. Thirty-first Annual Report, U.S. Bureau of American Ethnology, 1909-1910. Smithsonian Institution, Washington D.C. 
Boyd, R.T., 1999a. Strategies of Indian burning in the Willamette Valley. In: Boyd, R.T. (Ed.), Indians, Fire and the Land in the Pacific Northwest. Oregon State University Press, Corvallis.

Boyd, R.T., 1999b. The Coming of the Spirit of Pestilence: Introduced Infectious Diseases and Population Decline among Northwest Coast Indians, 1774 - 1874. University of Washington Press, Seattle.

Boyd, R.T., 2013. Lower Columbia Chinookan disease and demography. In: Boyd, R.T., Ames, K.M., Johnson, T.A. (Eds.), Chinookan Peoples of the Lower Columbia. University of Washington Press, Seattle, pp. 229-249.

Boyd, R.T., Ames, K.M., Johnson, T.A., 2013. Chinookan Peoples of the Lower Columbia. University of Washington Press, Seattle.

Boyd, R.T., Hajda, Y.P., 1987. Seasonal population movement along the lower Columbia River: the social and ecological context. American Ethnologist 14, 309-326.

Burley, D.V., 1980. Marpole: Anthropological Reconstructions of a Prehistoric Culture Type. Simon Fraser University, Burnaby.

Butler, V.L., Campbell, S.K., 2004. Resource intensification and resource depression in the Pacific Northwest of North America: a zooarchaeological review. Journal of World Prehistory $18,327-405$.

Butler, V.L., Martin, M., 2013. Aboriginal fisheries of the Lower Columbia River. In: Boyd, R.T., Ames, K.M., Johnson, T.A. (Eds.), Chinookan Peoples of the Lower Columbia River. University of Washington Press, Seattle, pp. 80-105.

Campbell, S.K., Butler, V.L., 2010. Fishes and loaves? Explaining sustainable, long-term animal harvesting on the Northwest Coast using the "plant paradigm". In: Dean., R.M. (Ed.), The Archaeology of Anthropogenic Environments. Center for Archaeological Investigations, Occasional Paper No. 37. Southern Illinois University, Carbondale.

Carballo, D.M., Roscoe, P., Feinman, G.M., 2014. Cooperation and collective action in the cultural evolution of complex societies. Journal of Archaeological Method and Theory 21, 98133.

Carlson, R.L., 1983. Prehistory of the Northwest Coast. In: Carlson, R.L. (Ed.), Indian Art Traditions of the Northwest Coast. Simon Fraser University Press, Burnaby, pp. 13-32.

Chatters, J.C., 1989. The antiquity of economic differentiation within households in the Puget Sound Region, Northwest Coast. In: MacEachern, S., Archer, D.J.W., Garvin, R.D. (Eds.), Households and Communities: Proceedings of the Twenty-first Annual Conference of the Archaeological Association of the University of Calgary. Archaeological Association, University of Calgary, Calgary, pp. 168-178.

Childe, V.G., 1950. The urban revolution. The Town Planning Review 21, 3-17. 
Chittenden, N.H., 1884. Official Report of the Exploitation of the Queen Charlotte Island for the Government of British Columbia. Project Gutenberg Ebook.

http://www.gutenberg.org/cache/epub/6596/pg6596-images.html. Accessed 6 January, 2018.

Christy, J.A., Alverson, E.R., 2011. Historical vegetation of the Willamette Valley, Oregon, circa 1850. Northwest Science 85, 93-107.

Cook, S., 1976a. The Indian Population of New England in the Seventeenth Century. University of California Publications in Anthropology 12, Berkeley.

Cook, S., 1976b. The Population of California Indians, 1769-1970. University of California Press, Berkeley and Los Angeles.

Coudart, A., 2015. The Bandkeramik longhouses: a material, social, and mental metaphor for small-scale sedentary societies. In: Fowler, C., Harding, J., Hofmann, D. (Eds.), The Oxford Handbook of Neolithic Europe. Oxford University Press, Oxford, pp. 309-326.

Countryman, D., Kemperman, J.A., 2000. Forest Reference Handbook. Iowa State University, Ames.

Coupland, G., 1985. Household variability and status differentiation at Kitselas Canyon. Canadian Journal of Archaeology 9, 39-56.

Coupland, G., Clark, T., Palmer, A., 2009. Hierarchy, communalism, and the spatial order of Northwest Coast plank houses: a comparative study. American Antiquity 74, 77-106.

Coupland, G., Martindale, A., Marsden, S., 2001. Does resource abundance explain local group rank among the coast Tsimshian? In: Cybulski, J.S. (Ed.), Perspectives on Northern Northwest Coast Prehistory. Mercury Series, Archaeology Survey of Canada Paper 160, Canadian Museum of Civilization, Hull, Quebec, pp. 223-248.

Daehnke, J.D., 2007. A 'strange multiplicity' of voices: heritage stewardship, contested sites and colonial legacies on the Columbia River. Journal of Social Archaeology 7, 250-275.

Daehnke, J.D. 2017. Chinook Resilience: Heritage and Cultural Revitalization on the Lower Columbia River. University of Washington Press, Seattle.

DeMarrais, E., Earle, T., 2017. Collective Action Theory and the Dynamics of Complex Societies. Annual Review of Anthropology 46, 183-201.

Deur, D., 2002. Rethinking precolonial plant cultivation on the northwest coast of North America. The Professional Geographer 54, 140-157. 
Deur, D., 2005. Tending the garden, making the soil: Northwest Coast estuarine gardens as engineered environments. In: Deur, D., Turner, N.J. (Eds.), Keeping It Living. University of Washington Press, Seattle, pp. 296-330.

Deur, D., Turner, N.J., 2005. Introduction: reassessing indigenous resource management, reassessing the history of an idea. In: Deur, D., Turner, N.J. (Eds.), Keeping It Living: Traditions of Plant Use and Cultivation on the Northwest Coast of North America. University of Washington Press, Seattle, Washington, pp. 3-34.

Deu, D., Dick, A., Recalma-Clutesi, K., Turner, N., 2015. Kwakwaka'wakw “Clam Gardens”: Motive and Agency in Traditional Northwest Coast Mariculture. Human Ecology 43, 201-212. Donald, L., 1997. Aboriginal Slavery on the Northwest Coast of North America. University of California Press, Berkeley.

Donald, L., Mitchell, D.H., 1975. Some correlates of local group rank among the southern Kwakiutl. Ethnology 14, 325-346.

Douglass, J.G., Gonlin, N., 2012. The household as analytical unit: case studies from the Americas. In: Douglass, J.G., Gonlin, N. (Eds.), Ancient Households of the Americas: Conceptualizing What Households Do. University Press of Colorado, Boulder, pp. 1-48.

Drucker, P.K., 1951. The Northern and Central Nootkan Tribes. The Smithsonian Institution, Washington D.C.

Drucker, P.K., 1966. Culture element distributions. In: McFeat, T. (Ed.), Indians of the North Pacific Coast. University of Washington Press, Seattle, pp. 261-266.

Earle, T., Spriggs, M., 2015. Political economy in prehistory: a Marxist approach to Pacific sequences. Current Anthropology 56, 515-544.

Ellis, D.V., 2006. Of a more temporary cast: household production at the Broken Tops Site. In: Sobel, E.A., Gahr, D.A.T., Ames, K.M (Eds.), Household Archaeology on the Northwest Coast. International Monographs in Prehistory, Ann Arbor, pp. 120-139.

Ellis, D.V., 2013. Cultural geography of the Lower Columbia. In: Boyd, R.T., Ames, K.M., Johnson, T.A. (Eds.), Chinookan Peoples of the Lower Columbia. University of Washington Press, Seattle, pp. 42-62.

Erasmus, C.J., 1965. Monument building: some field experiments. Southwestern Journal of Anthropology, 21, 277-301.

Fagan, J.L., 1985. Experimental archaeology and public involvement: a case study. In: Plew, M.G., Woods, J.C., Pavesic, M.G. (Eds.), Stone Tool Analysis: Essays in Honor of Don C. Crabtree. University of New Mexico Press, Albuquerque, pp. 161-186. 
Fladmark, K.R., 1973. The Richardson Ranch Site: a 19th century Haida house. In: Getty, R.M., Fladmark, K.R. (Eds.), Historical Archaeology on Northwestern North America. Archaeological Association, University of Calgary, Calgary, pp. 53-95.

Fladmark, K.R., 1975. A Paleoecological Model for Northwest Coast Prehistory. Mercury Series, Canadian Museum of Civilization, Ottawa.

Forest Products Laboratory, 2010. Wood as an Engineering Material. General Technical Report FPL-GTR-190. US Department of Agriculture Forest Service, Madison.

Gahr, D.A.T., 2006. Architects to ancestors: the life cycle of plankhouses. In: Sobel, E.A., Gahr, D.A.T., Ames, K.M. (Eds.), Household Archaeology on the Northwest Coast. International Monographs in Prehistory, Archaeological Series 16., Ann Arbor, pp. 56-70.

Gahr, D.A.T., 2013. Ethnobiology: nonfishing subsistence and production. In: Boyd, R.T., Ames, K.M., Johnson, T.A. (Eds.), Chinookan Peoples of the Lower Columbia. University of Washington Press, Seattle, pp. 63-79.

Gardner-O'Kearney, W., 2017. Domestic hearth features at the Cathlapotle (45CL1) and Meier (35CO5) sites in the Wapato Valley of Oregon and Washington. In: Ames, K.M., Henry, K. (Eds.), Architecture, Fire, and Storage: Cathlapotle and Meier Features. Wapato Valley Archaeological Project Reports \#9. Portland State University/U.S. Fish and Wildlife Service, Portland, pp. 143-264.

Gillespie, S.D., 2000a. Beyond kinship: introduction. In: Joyce, R.A., Gillespie, S.D. (Eds.), Beyond Kinship: Social and Material Reproduction in House Societies. University of Pennsylvania Press, Philadelphia, pp. 1-21.

Gillespie, S.D., 2000b. Levi-Strauss: maison and societe a maisons. In: Joyce, R.A., Gillespie, S.D. (Eds.), Beyond Kinship: Social and Material Reproduction in House Societies. University of Pennsylvania Press, Philadelphia, pp. 22-52.

Gillespie, S.D., 2007. When is a house, in: Robin A. Beck, J. (Ed.), The durable house: House society models in archaeology. Occasional Paper No. 35. Center for Archaeological Investigation, Southern Illinois University, Carbondale, pp. 25-43.

Gintis, H., 2007. The evolution of private property. Journal of Economic Behavior \& Organization 64, 1-16.

Goddard, P.E., 1972. Indians of the Northwest Coast. Cooper Square Publishers, New York.

Grier, C., 2001. The Social Economy of a Prehistoric Northwest Coast Plankhouse, Unpublished Ph.D. Dissertation, Department of Anthropology. Arizona State University, pp. 313.

Grier, C., 2006a. Political dimensions of monumental residences on the Northwest Coast of North America. In: Christie, J.J., Sarro, P.J. (Eds.), Palaces and power in the Americas: from Peru to the Northwest Coast. University of Texas Press, Austin, pp. 141-165. 
Grier, C., 2006b. Temporality in Northwest Coast households. In: Sobel, E.A., Gahr, D.A.T., Ames, K.M (Eds.), Household Archaeology on the Northwest Coast. International Monographs in Prehistory, Archaeological Series 16, Ann Arbor, pp. 97-119.

Grier, C., 2007. Consuming the recent for constructing the ancient: the role of ethnography in Coast Salish archaeological interpretation. In: Miller, B.G. (Ed.), Be of Good Mind: Essays on the Coast Salish. University of British Columbia Press, Vancouver, pp. 284-307.

Grier, C., 2014. Landscape construction, ownership and social change in the Southern Gulf Islands of British Columbia. Canadian Journal of Archaeology/Journal Canadien d'Archéologie 38, 211-249.

Grier, C., Angelbeck, B., McLay, E., 2017. Terraforming and monumentality as long-term social practice in the Salish Sea region of the Northwest Coast of North America. Hunter-Gatherer Research 3, 107-132.

Grier, C., Kim, J., 2012. Resource control and the development of political economies in smallscale societies: contrasting prehistoric southwestern Korea and the Coast Salish region of northwestern North America. Journal of Anthropological Research 68, 1-34.

Grier, C., Scwadron, M., 2017. Terraforming and monumentality in hunter-gatherer-fisher societies. Hunter-Gatherer Research 3, 3-8.

Groesbeck, A.S., Rowell, K., Lepofsky, D., Salomon, A.K., 2014. Ancient clam gardens increased shellfish production: adaptive strategies from the past can inform food security today. PloS one 9, e91235.

Grove, J.M., 1988. The Little Ice Age. Routledge, New York.

Hakansson, N.T., Widgren, M., 2014. Landesque capital: the historical ecology of enduring landscape modifications. Left Coast Press, Walnut Creek.

Hajda, Y., 1984. Regional Social Organization in the Greater Lower Columbia, 1792-1830. University of Washington, Seattle.

Hajda, Y., 1994. Notes on Indian Houses of the Wappato Valley. Northwest Anthropological Research Notes 28, 177 - 188.

Hajda, Y., 2005. Slavery in the Greater Lower Columbia Region. Ethnohistory 52, 563 -588.

Harrington, C.A., 2003. The 1930s Survey of Forest Resources in Washington and Oregon. General Technical Report PNW-GTR-584. U.S. Department of Agriculture, Forest Service, Pacific Northwest Forest Research Station, Portland. 
Hodges, C., 2017. Response to chronic flooding at Cathlapotle (45CL1) Clark County, Washington stratigraphic analysis of Profile D, 155-159 N/W92. In: Ames, K.M., Henry, K. (Eds.), Geoarchaeology and Miscellaneous Reports: Cathlapotle and Meier Archaeological Sites, Lower Columbia River. Wapato Valley Archaeological Project Reports \#13. Portland State University/U.S. Fish and Wildlife Service, Portland, pp. 41-52.

Hoffmann, T., Lyons, N., Miller, D., Diaz, A., Homan, A., Huddlestan, S., Leon, R., 2016. Engineered feature used to enhance gardening at a 3800-year-old site on the Pacific Northwest Coast. Science Advances 2, e1601282.

Hoffmann, D., Smyth, J., 2013. Tracking the Neolithic House in Europe: Sedentism, Architecture and Practice. Springer, New York.

Huelsbeck, D.R., 1988. The surplus economy of the Central Northwest Coast. In: Iaaac, B.L. (Ed.), Prehistoric Economies of the Pacific Northwest Coast. Research, In: Economic Anthropology. Supplement 3. JAI Press, Greenwich, pp. 149-178.

Idaho Forest Products Commission, 2018. How Much Wood Goes into A House. Idaho Forest Products Commision, Boise. URL http://www.idahoforests.org/woodhous.htm. Accessed 1 January, 2018.

Jewitt, J.R., 1987. The Adventurers and Sufferings of John R Jewitt: Captive of Maquinna. University of Washington Press, Seattle.

Johnson, A.W., Earle, T.K., 2000. The evolution of human societies: from foraging group to agrarian state. Stanford University Press, Stanford.

Jordan, P., O'Neill, S., 2010. Untangling cultural inheritance: language diversity and long-house architecture on the Pacific northwest coast. Philosophical Transactions of the Royal Society B: Biological Sciences 365, 3875-3888.

Kidder, T.R., 2011. Transforming hunter-gatherer history at Poverty Point. In: Sassaman, K.E., Holly, D.H. (Eds.), Hunter-Gatherer Archaeology as Historical Process. University of Arizona Press, Tucson, pp. 95-119.

Kintigh, K.W., Altschul, J.H., Beaudry, M.C., Drennan, R.D., Kinzig, A.P., Kohler, T.A., Limp, W.F., Maschner, H.D.G., Michener, W.K., Pauketat, T.R., Peregrine, P., Jeremy A. Sabloff, Wilkinson, T.J., Wright, H.T., Zeder, M.A., 2014. Grand challenges for archaeology. American Antiquity 79, 5-24.

Koppert, V.A., 1930. Contributions to Clayoquot Ethnology. The Catholic University of America, Washington D.C.

Lacourse, T., Mathewes, R.W., Hebda, R.J., 2007. Paleoecological analysis of lake sediments reveal prehistoric human impact on forests at Anthony Island UNESCO World Heritage Site, Queen Charlotte Islands (Haida Gwaii), Canada. Quaternary Research 68:68, 177-183. 
Lepofsky, D., Pegg, B., 1996. Archaeological and Ethnographic Assessment, The Kawesas Watershed Assessment. Ecotrust, Portland.

Lepofsky, D., Schaepe, D.M., Graesch, A.P., Lenert, M., Ormerod, P., Carlson, K.T., Arnold, J.E., Blake, M., Moore, P., Clague, J.J., 2009. Exploring Stó:Lō-Coast Salish interaction and identity in ancient houses and settlements in the Fraser Valley, British Columbia. American Antiquity 74, 595-626.

Lepofsky, D., Smith, N.F., Cardinal, N., Harper, J., Morris, M., White, G.E., Bouchard, R., Kennedy, D.I.D., Salomon, A.K., Puckett, M., Rowel, K., 2015. Ancient shellfish mariculture on the Northwest Coast of North America. American Antiquity 80, 236-259.

Lesher, R.D., Henderson, J.A., 2010. Ecology and Distribution of Western Redcedar and Alaskan Yellowcedar in Northwestern Washington, A Tale of Two Cedars: International Symposium on Western Redcedar and Yellow-Cedar. General Technical Report PNW-GTR828,. US Department of Agriculture, Forest Service, Pacific Northwest Research Station, , Portland, pp. 13-18.

Letham, B., 2017. Long-term Human-Environment Interaction on Dynamic Coastal Landscapes: Examples from 15,000 years of Shoreline and Settlement Change in the Prince Rupert Harbour Area, Unpublished Ph.D. Dissertation, Anthropology. University of British Columbia, Vancouver.

Letham, B., Martindale, A., McLaren, D., Brown, T., Ames, K.M., Archer, D., Marsden, S., 2015. Holocene settlement history of the Dundas Islands Archipelago, Northern British Columbia. BC Studies 187, 51-85.

Letham, B., Martindale, A., Supernant, K., Brown, T.J., Cybulski, J.S., Ames, K.M., 2017. Assessing the scale and pace of large shell-bearing site occupation in the Prince Rupert Harbour Area, British Columbia. Journal of Island and Coastal Archaeology. DOI:

10.1080/15564894.2017.1387621

Levi-Strauss, C., 1983. The Way of the Masks (Trans. by S. Modelski). University of Washington Press, Seattle.

Lightfoot, K.G., 2006. Missions, furs, gold, and manifest destiny: rethinking an archaeology of colonialism for western North America. In: Hall, M., Silliman, S.W. (Eds.), Historical Archaeology, Blackwell Studies in Global Archaeology. Blackwell Publishing, Malden, pp. 272292.

MacDonald, G.F., 1983. Haida Monumental Art. University of Washington Press, Seattle.

MacDonald, G.F., 1984. The Epic of Nekt: the archaeology of metaphor. In: Seguin, M. (Ed.), The Tsimshian: Images of the Past Views of the Present. University of British Columbia Press, Vancouver, pp. 65-81. 
Mackie, A.P., Williamson, L., 2003. Nuu-chah-nulth houses: structural remains and cultural depressions on southwest Vancouver Island. In: Matson, R.G., Coupland, G., Mackie, Q. (Eds.), Emerging from the Mist: Studies in Northwest Coast Culture History. University of British Columbia Press, Vancouver, pp. 105-151.

Marshall, Y., 1989. The house in Northwest Coast, Nuu-chah-nulth, society: the material structure of political action. In: MacEachern, S., Archer, D.J.W., Garvin, R.D. (Eds.), Households and Communities. Chacmool, The Archaeological Association of the University of Calgary, Calgary, pp. 15-21.

Marshall, Y., 2000. Transformations of Nuu-chah-nulth Houses, in: Joyce, R.A., Gillespie, S.D. (Eds.), Beyond Kinship: Social and Material Reproduction in House Societies. University of Pennsylvania Press, Philadelphia, pp. 73-102.

Marshall, Y., 2006. Houses and domestication on the Northwest Coast. In: Sobel, E.E., Gahr, D.A.T., Ames, K.M. (Eds.), Household Archaeology on the Northwest Coast. Archaeological Series 16. International Monographs in Prehistory, Ann Arbor, pp. 37-56.

Martindale, A., Marsden, S., Patton, K., Ruggles, A., Letham, B., Supernant, K., Archer, D., McLaren, D., Ames, K.M., 2017a. The role of small villages in Northern Tsimshian territory from oral and archaeological records. Journal of Social Archaeology 17, 285-325.

Martindale, A., Letham, B., Supernant, K., Brown, T., Edinborough, K., Duelks, J., Ames, K.M., 2017b. Urbanism in Northern Tsimshian archaeology. Hunter-Gatherer Research 3, 133-163.

Mason, A.R., 2017. Early houses in the Lower Fraser River Region. In: Mike K. Rousseau (Ed.), Archaeology of the Lower Fraser River Region. Archaeology Press, Simon Fraser University, Burnaby, pp. 209-216.

Mathews, D.L., Turner, N.J., 2017. Ocean cultures: Northwest Coast ecosystems and Indigenous management systems. In: Levin, P.S., Poe, M.R. (Eds.), Conservation for the Anthropocene Ocean: Interdisciplinary Science in support of Indigenous People. Elsevier, London, pp. 169206.

Matson, R.G., 1983. Intensification and the development of cultural complexity: the Northwest versus the Northeast Coast. In: Nash, R.J. (Ed.), The Evolution of Maritime Cultures on the Northeast and Northwest Coasts of America. Simon Fraser University, Burnaby, pp. 124-148.

Matson, R.G., 1985. The relationship between sedentism and status inequalities among huntergatherers. In: Thompson, M., Garcia, M.T., Kense, F.J. (Eds.), Status, Structure and Stratification: Current Archaeological Reconstructions. Archaeological Association of the University of Calgary, Calgary, pp. 245-252. 
Matson, R.G., Coupland G., 1995. The Prehistory of the Northwest Coast. Academic Press, Orlando.

Mauger, J.E., 1978. Shed Roof Houses at the Ozette Archaeological Site: A Protohistoric Architectural System. Washington Archaeological Research Center, Washington State University, Pullman.

Mitchell, D., Donald, L., 1988. Archaeology and the study of Northwest Coast economies. In: Isaac, B. (Ed.), Prehistoric Economies of the Northwest Coast. JAI Press, Inc., Greenwich, pp. 293-351.

Morgan, C., Webb, D., Sprengeler, K., Black, M.P., George, N., 2018. Experimental construction of hunter-gatherer residential features, mobility, and the costs of occupying "persistent places". Journal of Archaeological Science 91, 65-76.

Moss, M.L., 1993. Shellfish, gender, and status on the Northwest Coast: reconciling archaeological, ethnographic, and ethnohistorical records of the Tlingit. American Anthropologist 95, 631-652.

Moss, M.L., 1999. Engendering archaeology in the Pacific Northwest. Northwest Anthropological Research Notes 33, 245-262.

Moss, M.L., 2011. Northwest Coast: archaeology as deep history. Society for American Archaeology Press, Washington D.C.

Moss, M.L., 2012. Understanding variability in Northwest Coast faunal assemblages: beyond economic intensification and cultural complexity. Journal of Island \& Coastal Archaeology 7, 1 22.

Moss, M.L., Cannon, A., 2011. The Archaeology of North Coast Fisheries. University of Alaska Press, Fairbanks.

Moss, M.L., Erlandson, J.M., 1992. Forts, refuge rocks, and defensive sites: the antiquity of warfare along the North Pacific Coast of North America. Arctic Anthropology 29, 73-90.

Moulton, G.E., 1991. The Journals of the Lewis and Clark Expedition, Volume 7, March 23-June 9, 1806. University of Nebraska Press, Lincoln.

Niblack, A.P., 1970. Coast Indians of Southern Alaska and Northern British Columbia. Johnson Reprint Corporation, New York. Originally published 1888, Report of the National Museum, Washington D. C.

Oberg, K., 1943. A comparison of three systems of primitive economic organization. American Anthropologist New Series 45, 572-587. 
Ortmann, A.L., Kidder, T.R., 2013. Building Mound A at Poverty Point, Louisiana: monumental public architecture, ritual practice, and implications for hunter-gatherer complexity. Geoarchaeology: An International Journal 28, 66-86.

Ostrom, E., 1990. Governing the Commons: The Evolution of Institutions for Collective Action. Cambridge University Press, Cambridge.

Ostrom, E., 2000. Reformulating the commons. Swiss Political Science Review 6, 29-52.

Oxford English Dictionary. 1971. The Compact Oxford English Dictionary. Oxford University Press, Oxford

Poage, N., Tappeiner, J.C., 2005. Tree species and size structure of old-growth Douglas Fir forests in Central Western Oregon, USA. Forest Ecology and Management 204, 329-343.

Pojar, J., MacKinnon, A., 1994. Plants of the Pacific Northwest Coast: Washington, Oregon, British Columbia, and Alaska. Lone Pine Publishing, Edmonton.

Pratt, H., 1999. The search for gender in early Northwest Coast prehistory. Northwest Anthropological Research Notes 33, 229-234.

Reynolds, P.J., 1995. The life and death of a post-hole. Interpreting Stratigraphy 5, 21-26.

Richardson, A., 1981. The control of productive resources on the Northwest Coast of North America. In: Williams, N., Hunn, E.S. (Eds.), Resource Managers: North American and Australian Hunter-Gatherers, Westview Press, Boulder, pp. 93-112.

Rodning, C.B., 2007. Building and Rebuilding Cherokee Houses and Townhouses in Southwestern North Carolina, in: Beck, R.A. (Ed.), The Durable House: House Society Models in Archaeology. Center for Archaeological Investigations Occasional Paper No. 35. Southern Illinois University, Carbondale, pp. 464-484.

Rodning, C.B., 2009. Mounds, myths, and Cherokee townhouses in southwestern North Carolina. American Antiquity 74, 627-663.

Ruyle, E., 1973. Slavery, surplus and stratification on the Northwest Coast: the ethnoenergetics of an incipient stratification system. Current Anthropology 14, 603-631.

Saitta, D. 2012. Research Orientation. Electronic document, https://portfolio.du.edu/dsaitta/page/4175, accessed May 15, 2018.

Saunders, J.W., Mandel, R.D., Saucier, R.T., Allen, E.T., Hallmark, C., Johnson, J.K., Jackson, E.H., Allen, C.M., Stringer, G.L., Frink, D.S., 1997. A mound complex in Louisiana at 54005000 years before the present. Science 277, 1796-1799. 
Schalk, R.F., 1977. The structure of an anadromous fish resource. In: Binford, L.R. (Ed.), For Theory Building in Archaeology: Essays on Faunal Remains, Aquatic Resources, and Systematic Modeling. Academic Press, Inc., New York, pp. 207-250.

Schmidt, K., 1998. Beyond daily bread: evidence of Early Neolithic ritual from GobeMi Tepe. Neo-Lithics: A Newsletter of Southwest Asian Lithics Research 2/98, 1-5.

Shepard, E.E., 2017. Building and maintaining plankhouses at two villages on the southern Northwest Coast of North America. In: Ames, K.M., Henry, K. (Eds.), Architecture, Fire, and Storage: Cathlapotle and Meier Features. Wapato Valley Archaeological Project Reports \#9. Portland State University/U.S. Fish and Wildlife Service, Portland, pp. 49-142.

Smith, C.M., 2008. The Organization of Production Among Sedentary Foragers of the Southern Pacific Northwest Coast Archaeopress, Oxford.

Smith, C.M., 2015. Use-wear, châıne opératoire and labour organisation among Pacific Northwest Coast sedentary foragers. Antiquity 89, 662-682.

Smith, D.J., Mackie, A.P., Sumpter, I.D., 2005. Building Quaksweaqwul: dendroarchaeological investigations at Kiix?in National Historic Site, Vancouver Island, Canada. Dendrochronologia 22, 195-201.

Sobel, E.A., 2006. Household prestige and obsidian use in the Lower Columbia River Valley: implications regarding prestige and exchange networks on the Northwest Coast. In: Sobel, E.A., Trieu, D.A., Ames, K.M. (Eds.), Household Archaeology on the Northwest Coast. International Monographs in Archaeology, Archaeological Series 16, Ann Arbor, pp. 159-199.

Sobel, E.A., 2011. The exchange expansion model of Contact Era Change on the Northwest Coast: an archaeological test using obsidian data from the Lower Columbia River. Journal of Anthropological Archaeology 31, 1-21.

Sobel, E.A., 2017. Social complexity and corporate households on the southern Northwest Coast of North America, A.D. 1450 - 1855. Wapato Valley Archaeological Project Reports \#8. In: Ames, K.M. (Ed.). Portland State University/U.S. Fish and Wildlife Service, Portland.

Sobel, E.A., Ames, K.M., Losey, R.J., 2013. Environment and archaeology of the Lower Columbia. In: Boyd, R.T., Ames, K.M., Johnson, T.A. (Eds.), Chinookan Peoples of the Lower Columbia. University of Washington Press, Seattle, pp. 23-41.

Souvatzi, S.G., 2008. A Social Archaeology of Households on Neolithic Greece: An Anthropological Approach. Cambridge University Press, Cambridge.

Stanish, C., 2017. The Evolution of Human Co-operation: Ritual and Social Complexity in Stateless Societies. University of Cambridge Press, Cambridge. 
Stanish, C., Tantaleán, H., Knudson, K., 2018. Feasting and the evolution of cooperative social organizations circa 2300 BP in Paracas culture, southern Peru. Proceedings of the National Academy of Sciences 115, E6716-E6721.

Steadman, S.R., 2015. Archaeology of Domestic Architecture and the Human Use of Space. Left Coast Press, Walnut Creek.

Steere, B.A., 2017. The Archaeology of Houses and Households in the Native Southeast. The University of Alabama Press, Tuscaloosa.

Stewart, H., 1984. Cedar: Tree of Life of the Northwest Coast Indians. University of Washington Press, Seattle.

Supernant, K., 2017. Archaeological petroforms of the Lower Fraser River Canyon. In: Mike K. Rousseau (Ed.), Archaeology of the Lower Fraser River Region. Simon Fraser University Archaeology Press, Burnaby, pp. 13-24.

Suttles, W., 1960. Affinal ties, subsistence and prestige among the Coast Salish. American Anthropologist 62, 296-305.

Suttles, W., 1990. Introduction. In: Suttles, W. (Ed.), Handbook of North American Indians, Vol. 7: The Northwest Coast. The Smithsonian Institution, Washington D. C., pp. 1-15.

Suttles, W., 1991. The shed-roof house. In: Wright, R.K. (Ed.), A Time of Gathering: Native Heritage in Washington State. University of Washington Press, Seattle, pp. 212-222.

Thompson, V.D., Marquardt, W.H., Walker, K.J., Thompson, A.D.R., Newsom, L.A., 2018. Collective action, state building, and the rise of the Calusa, southwest Florida, USA. Journal of Anthropological Archaeology 51, 28-44.

Thompson, V.D., Pluckhahn, T.J., 2010. History, complex hunter-gatherers, and the mounds and monuments of Crystal River, Florida, USA: a geophysical perspective. Journal of Island \& Coastal Archaeology 5, 33-51.

Thornton, T., Deur, D., Kitka, H., 2015. Cultivation of salmon and other marine resources on the Northwest Coast of North America. Human Ecology 43, 189-199.

Trant, A.J., Nijland, W., Hoffman, K.M., Mathews, D.L., McLaren, D., Nelson, T.A., Starzomski, B.M., 2016. Intertidal resource use over millennia enhances forest productivity. Nature Communications 7, DOI: 10.1038/ncomms12491.

Trosper, R.L., 2002. Northwest coast indigenous institutions that supported resilience and sustainability. Ecological Economics 41, 329-344

Trosper, R.L., 2009. Resilience, Reciprocity and Ecological Economics: Northwest Coast Sustainability. Routledge and Taylor and Francis Group, London and New York. 
Turner, N.J., 2014. Ancient Pathways, Ancient Knowledge: Ethnobotany and Ecological Wisdom of Indigenous Peoples of Northwestern North America (2 Volumes). McGill-Queens University Press, Montreal.

Turner, N.J., Davidson, F.E., 2004. Plants of Haida Gwaii. Sono Nis Press, Winlaw.

Vastokas, J.M., 1966. Architecture of the Northwest Coast Indians of America, Unpublished Ph.D. Dissertation, Department of Fine Arts. Columbia University, New York.

Walter, M.S., 2006. Polygyny, rank, and resources in Northwest Coast foraging societies. Ethnology 45, 41-57.

Waring, R.H., Franklin, J.F., 1979. Evergreen coniferous forests of the Pacific Northwest. Science 204, 1380-1386.

Wessen, G., 1988. The use of shellfish resources on the Northwest Coast: the view from Ozette. In: Isaac, B. (Ed.), Research in Economic Anthropology. JAI Press, Greenwich, pp. 179-210.

Wilk, R.R., Netting, R.M., 1984. Households: changing forms and functions. In: Netting, R.M., Wilk, R.R., Arnould, E.J. (Eds.), Households: Comparative and Historical Studies of the Domestic Group. University of California Press, Berkeley, pp. 1-28.

Williams, J., 2006. Clam Gardens: Aboriginal Mariculture on Canada's West Coast. New Star Books, Vancouver.

Wilson, C., 1866. Report on the Indian Tribes Inhabiting the Country in the Vicinity of the 49th Parallel of North Latitude. Transactions of the Ethnological Society of London 4, 275-332.

Wylie, A., 1989. Archaeological cables and tacking: the implications of practice for Bernstein's "options beyond objectivism and relativism". Philosophy of Science 19, 1-18.

Zenk, H., Hajda, Y., Boyd, R.T., 2016. Chinookan villages of the Lower Columbia. Oregon Historical Quarterly 117, 6-37. 
Table 1

Population estimates for various entities discussed in the text.

\begin{tabular}{lr}
\hline Entity & Estimate $^{\mathrm{a}}$ \\
\hline Meier & 203 \\
Cathlapotle Total & 666 \\
House 1B & 27 \\
House 1C & 47 \\
House 1D & 77 \\
House 1 Total & 151 \\
House 4 & 38 \\
Wapato Valley Lewis and Clark Low & $\mathrm{c}$ \\
Wapato Valley Lewis and Clark High & 3400 \\
\hline
\end{tabular}

${ }^{\mathrm{a}}$ From Ames 2008

${ }^{\mathrm{b}}$ Excludes House 1A (unexcavated)

${ }^{\mathrm{c}}$ Boyd and Hajda 1987 
Table 2

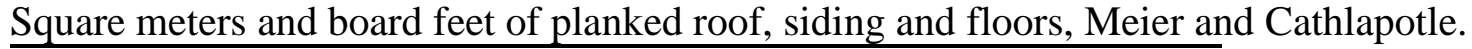

\begin{tabular}{lccr} 
& Surface Area $\left(\mathrm{m}^{2}\right)$ & \multicolumn{2}{c}{ Board Feet } \\
& Range & Range & Median \\
\hline Meier with floor & $1033-1158$ & $33,351-37,401$ & 35376 \\
Meier without floor & $613-738$ & $19,789-23,838$ & 21814 \\
Cathlapotle House 4 & $210-277$ & $6775-8,946$ & 7861 \\
Cathlapotle House 1B & $149-199$ & $4798-6419$ & 5609 \\
Cathlapotle House 1C & $215-280$ & $6954-9036$ & 7995 \\
Cathlapotle House 1D & $320-407$ & $10,339-13,155$ & 11747 \\
Cathlapotle House 1 Total* & $1098-1389$ & $38,699-44,867$ & 41783 \\
\hline
\end{tabular}

*Includes six short axis sides representing compartment dividers. Does not include House 1A. 
Table 3

Trees represented in initial house construction, Meier and Cathlapotle. The number of trees represented in the Wapato Valley houses was derived by multiplying the median by 154 .

\begin{tabular}{|c|c|c|c|c|c|}
\hline & $\begin{array}{l}\text { Siding, } \\
\text { Roofing and } \\
\text { Flooring* } \\
\text { Range }\end{array}$ & $\begin{array}{c}\text { Posts and } \\
\text { Beams** } \\
\text { Range }\end{array}$ & Total & Median & $\begin{array}{c}\text { Wapato } \\
\text { Valley } \\
\text { Houses } \\
(154)\end{array}$ \\
\hline Meier with floor & $29-33$ & $22-30$ & $51-63$ & 57 & 8778 \\
\hline $\begin{array}{l}\text { Meier without } \\
\text { floor }\end{array}$ & $17-21$ & $22-30$ & $39-51$ & 45 & 6930 \\
\hline $\begin{array}{l}\text { Cathlapotle } \\
\text { House } 4\end{array}$ & $6-8$ & $10-13$ & $16-21$ & 19 & 2849 \\
\hline $\begin{array}{l}\text { Cathlapotle } \\
\text { House } 1\end{array}$ & $31-39$ & $47-63$ & $78-102$ & 90 & 13,860 \\
\hline
\end{tabular}

* Derived from board feet

** Derived from circular wood calculations 
Table 4 Person Days associated with house construction tasks.

\begin{tabular}{llccc}
\hline Production Step & Specific Task & Meier & $\begin{array}{c}\text { Cathlapotle } \\
\text { House 4 }\end{array}$ & $\begin{array}{c}\text { Cathlapotle } \\
\text { House 1 }\end{array}$ \\
\hline Planning & Plan architecture and labor & Unknown & Unknown & Unknown \\
& Prepare tools & Unknown & Unknown & Unknown \\
\hline Procure materials & Locate and select trees & Unknown & Unknown & Unknown \\
& Fell trees & $38-304$ & $10-104$ & $48-489$ \\
& Transport logs & Unknown & Unknown & Unknown \\
\hline Prepare materials & Split and adze wood & Unknown & Unknown & Unknown \\
& Excavate soil & $101-375$ & $37-124$ & $116-546$ \\
\hline Construction & Frame and sheath house & $1,273-2,211$ & $324-563$ & $1,994-3,463$ \\
& Build furnishings & Unknown & Unknown & Unknown \\
& Feed and organize laborers & Unknown & Unknown & Unknown \\
\hline Total excluding unknown labor estimates & $1,412-2,890$ & $371-791$ & $2,158-4,498$ \\
\hline Median & & 2184 & 606 & 3419 \\
\hline
\end{tabular}


Table 5 Weight of Wood Material in Metric Tons Needed for Initial Construction, Meier and Cathlapotle.

\begin{tabular}{lcccc}
\hline & Planks for Siding & Posts and Beams & Total & Median \\
& Range & Range & & \\
\hline Meier with floor & $47-53$ & $6-31$ & $53-84$ & 69 \\
Meier without floor & $28-34$ & $6-31$ & $33-65$ & 49 \\
Cathlapotle House 4 & $10-13$ & $4-16$ & $13-29$ & 21 \\
Cathlapotle House 1 & $50-63$ & $12-72$ & $65-135$ & 100 \\
\hline
\end{tabular}


Table 6

Gahr's estimates of single-day house raising, Meier and Cathlapotle. The low labor estimate is based on 1 person/.19 $\mathrm{m}^{2}$ of floor area; the high labor estimate on 1 person/.33 $\mathrm{m}^{2}$ floor area (Gahr 2006). See text for discussion on Lewis and Clark's low and high population estimates.

\begin{tabular}{lccccc}
\hline House & $\begin{array}{c}\text { Floor Area } \\
\left(\mathrm{m}^{2}\right)\end{array}$ & $\begin{array}{c}\text { Low Labor } \\
\text { Estimate (Number } \\
\text { of People) }\end{array}$ & $\begin{array}{c}\text { High Labor } \\
\text { Estimate } \\
\text { (Number of } \\
\text { People) }\end{array}$ & $\begin{array}{c}\text { \% Lewis and } \\
\text { Clark Low } \\
\text { Population } \\
\text { Estimate }\end{array}$ & $\begin{array}{c}\text { \% Lewis and } \\
\text { Clark High } \\
\text { Population } \\
\text { Estimate }\end{array}$ \\
\hline Meier & 420 & 1,273 & 2,211 & $42-72$ & $16-28$ \\
Cathlapotle House 1 & 658 & 1,994 & 3,463 & $65-113$ & $25-44$ \\
Cathlapotle House 4 & 132 & 400 & 695 & $13-23$ & $5-9$ \\
\hline
\end{tabular}

*Numbers differ slightly from Gahr's calculations because of different house metrics employed. 
Table 7

Total Planking Needs for House Lifespan (Walls, Roof and Floor), Meier and Cathlapotle. Board Feet

\begin{tabular}{lcc} 
& Low Range & High Range \\
\hline Meier with floor & 667,024 & 748,012 \\
Meier without floor & 395,771 & 476,759 \\
Cathlapotle House 4 & 135,497 & 178,924 \\
Cathlapotle House 1 & 878,461 & $1,018,470$ \\
\hline
\end{tabular}




\section{Table 8}

Numbers of Trees Needed for Replacement of Planks and Posts over the House's Lifespan.

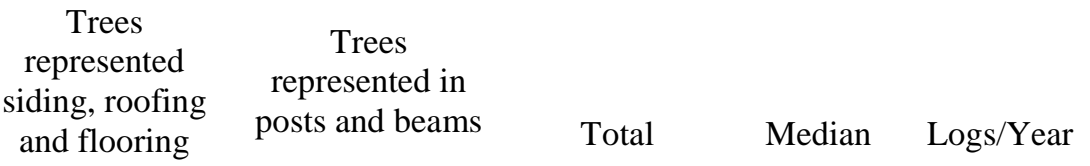

\begin{tabular}{|c|c|c|c|c|c|}
\hline & Range* & Range** & & & \\
\hline $\begin{array}{l}\text { Meier with } \\
\text { floor }\end{array}$ & $595-666$ & $137-625$ & $732-1292$ & 1012 & 3 \\
\hline $\begin{array}{l}\text { Meier without } \\
\text { floor }\end{array}$ & $353-425$ & $137-625$ & $490-1051$ & 770 & 2 \\
\hline $\begin{array}{l}\text { Cathlapotle } \\
\text { House } 4\end{array}$ & $116-153$ & $39-242$ & $155-395$ & 275 & 1 \\
\hline $\begin{array}{l}\text { Cathlapotle } \\
\text { House } 1 \text { Total }\end{array}$ & $764-885$ & $260-1395$ & $1024-2280$ & 1652 & 4 \\
\hline
\end{tabular}

*Tree estimates derived from board feet $(1 \mathrm{~m}$ diameter $\operatorname{logs})$. **Tree estimates derived from meters of logs. 


\section{List of Figures}

Figure 1 Idealized interior of a Meier/Cathlapotle house. Not to scale; actual pit complexes, for example, are 1 to $2 \mathrm{~m}$ deep. Original drawing by Cameron McP. Smith.

Figure 2 Map of the Greater Lower Columbia River Region showing sites mentioned in the text and the location of the Wapato Valley (aka Portland Basin).

Figure 3 Cathlapotle showing positions of houses and excavation units.

Figure 4 Meier showing position of house and excavation units.

Figure 5 Structural features, Cathlapotle House 1.

Figure 6 Structural features Cathlapotle House 4.

Figure 7 Structural feature Meier House. 